\title{
Bioprospecting of novel thermostable $\beta$-glucosidase from Bacillus subtilis RA10 and its application in biomass hydrolysis
}

\author{
Rameshwar Tiwari ${ }^{1,2,3}$, Puneet Kumar Singh', Surender Singh², Pawan K. S. Nain ${ }^{4}$, Lata Nain ${ }^{2}$ \\ and Pratyoosh Shukla ${ }^{1 *}$ (i)
}

\begin{abstract}
Background: Saccharification is the most crucial and cost-intensive process in second generation biofuel production. The deficiency of $\beta$-glucosidase in commercial enzyme leads to incomplete biomass hydrolysis. The decomposition of biomass at high temperature environments leads us to isolate thermotolerant microbes with $\beta$-glucosidase production potential.

Results: A total of 11 isolates were obtained from compost and cow dung samples that were able to grow at $50^{\circ} \mathrm{C}$. On the basis of qualitative and quantitative estimation of $\beta$-glucosidase enzyme production, Bacillus subtilis RA10 was selected for further studies. The medium components and growth conditions were optimized and $\beta$-glucosidase enzyme production was enhanced up to 19.8 -fold. The $\beta$-glucosidase from B. subtilis RA10 retained $78 \%$ of activity at $80^{\circ} \mathrm{C}$ temperature and $68.32 \%$ of enzyme activity was stable even at $50^{\circ} \mathrm{C}$ after $48 \mathrm{~h}$ of incubation. The supplementation of $\beta$-glucosidase from B. subtilis RA10 into commercial cellulase enzyme resulted in 1.34-fold higher glucose release. Furthermore, $\beta$-glucosidase was also functionally elucidated by cloning and overexpression of full length GH1 family $\beta$-glucosidase gene from B. subtilis RA 10. The purified protein was characterized as thermostable $\beta$-glucosidase enzyme.
\end{abstract}

Conclusions: The thermostable $\beta$-glucosidase enzyme from B. subtilis RA10 would facilitate efficient saccharification of cellulosic biomass into fermentable sugar. Consequently, after saccharification, thermostable $\beta$-glucosidase enzyme would be recovered and reused to reduce the cost of overall bioethanol production process.

Keywords: Thermotolerant, Thermostable $\beta$-glucosidase, Saccharification, Cloning and expression, Molecular modelling

\section{Background}

Second generation biofuel production has been proposed as a sustainable and alternative energy option to sustain global energy demand [1]. Since, cellulose is the most abundant renewable biopolymer produced photosynthetically, the ultimate aim is to develop an economic industrially feasible process for conversion of lignocellulosic biomass into biofuel molecules [2]. The efficient

\footnotetext{
${ }^{*}$ Correspondence: pratyoosh.shukla@gmail.com

1 Enzyme Technology and Protein Bioinformatics Laboratory, Department of Microbiology, Maharshi Dayanand University, Rohtak, Haryana 124001, India

Full list of author information is available at the end of the article
}

hydrolysis of cellulose is most important step to develop biobased refineries. The saccharification step needs cellulases which have higher hydrolytic efficiency with increased stability at diverse $\mathrm{pH}$, temperature and tolerance to end product inhibition $[3,4]$. Among the cellulase enzyme complex, $\beta$-glucosidase is the rate-limiting enzyme and most of the fungal enzyme preparation do not produce sufficient $\beta$-glucosidase enzyme for complete conversion of cellulose into monomeric sugars [5]. Therefore, the main aim of the study to isolate novel $\beta$-glucosidase producers from unique habitats.

$\beta$-Glucosidases are widely distributed in the living world and they play pivotal roles in many biological 
processes. The physiological roles associated with this enzyme are diverse and depend on the location of the enzyme and the biological system in which these occur. In cellulolytic microorganisms, $\beta$-glucosidase is involved in cellulase induction and cellulose hydrolysis. In plants, the enzyme is involved in $\beta$-glucan synthesis during cell wall development, pigment metabolism, fruit ripening and defense mechanisms, whereas in humans and other mammals, $\beta$-glucosidases are thought to play a role in metabolism of glycolipids and dietary glucosides. Due to their wide and varied roles in nature, these versatile enzymes can be used in several industrial applications.

The microbial community can exist in the most diverse and extreme condition of this earth [6]. These 'extremophiles' are known to produce biocatalysts with special functional adaptation [7]. Consequently, the environmental samples from different niches may be explored for the novel biocatalysts with the unique characteristics which may find application in industries $[8,9]$. Although there are several reports available on microbial community analysis from diverse extreme environments, the microbial community of herbivorous intestine is less explored which may be the main source of diverse hydrolytic enzymes involved in degradation of cellulose [10, 11]. Secondly, compost obtained from agricultural residues is also a rich habitat for lignocellulolytic microorganism, as it contains all organic substrates necessary for the growth of diverse microbial population $[12,13]$. Therefore, both the niches were investigated for isolation of thermotolerant microorganisms with high $\beta$-glucosidase enzyme activities.

Selection for the potential $\beta$-glucosidase enzymes with enhanced activities remains a confront for the biorefinery industry to obtain efficient enzymatic hydrolysis of biomass [14]. With the advancement of recombinant DNA technology (RDT), now it is possible to overexpress the enzyme of interest in high titer with the ease of downstream processing for product development [15]. This technique has been successfully opted to produce industrially important biocatalysts and also open new avenues to understand the structure-function relationship. In this study, RDT was adapted for heterologous overexpression of glycosyl hydrolase family $1 \beta$-glucosidase $(B g l \mathrm{~B})$ from B. subtilis RA10.

\section{Methods}

\section{Sample collection, enrichment and isolation of cellulolytic} microorganisms

Compost $(\mathrm{CM})$ prepared from paddy straw as raw material was collected from the compost pits of Division of Microbiology, IARI, New Delhi, India, in the month of September (2013). At the time of samples collection, compost heap was in the thermophilic phase with temperature ranging between 60 and $65{ }^{\circ} \mathrm{C}$. Cow dung (CD) was collected from dairy farm situated in Todapur village, New Delhi, India. For isolation of cellulolytic microorganisms, the samples were enriched with $\alpha$-cellulose or cellobiose. Samples $(5 \mathrm{~g})$ were incubated in $100 \mathrm{~mL}$ Erlenmeyer flask with $50 \mathrm{~mL}$ of Reese's minimal medium (RMM) with $1 \%$ cellobiose. Enrichment flasks were incubated at $45{ }^{\circ} \mathrm{C}$ for 10 days. The diluted enriched medium was spread plated over the solid Reese's minimal medium containing respective substrate and plates were incubated at $45^{\circ} \mathrm{C}$ for 7 days.

\section{Qualitative screening of isolates for $\beta$-glucosidase production ability}

Initially, selected morphotypes were qualitatively screened for $\beta$-glucosidase activity by testing them on RMM agar medium containing $0.5 \%$ esculin and $0.1 \%$ ammonium iron (III) citrate [11]. Isolates were grown overnight in nutrient broth at $45^{\circ} \mathrm{C}$ and further cultures were spotted on esculin plates and incubated at $45^{\circ} \mathrm{C}$ for $48 \mathrm{~h}$. The $\beta$-glucosidase producing isolates were selected based on appearance of black zone around the colonies indicating the hydrolysis of esculin.

\section{Quantitative screening of isolates during growth on different carbon sources under submerged fermentation}

The selected isolates based on esculin hydrolysis were screened for the production of $\beta$-glucosidase enzyme using different cellulosic carbon sources (Avicel PH101, Sigmacell 101, $\alpha$-cellulose and cellobiose). This quantitative screening was performed under submerged fermentation using RMM containing $1 \%$ of these cellulosic substrates. Overnight grown culture was used as inoculum and flasks were incubated at $45{ }^{\circ} \mathrm{C}$ for $48 \mathrm{~h}$ in incubator shaker $(150 \mathrm{rpm})$. All experiments were performed in triplicate. After growth, the medium was centrifuged at $10,000 \mathrm{~g}$ for $10 \mathrm{~min}$ at $4{ }^{\circ} \mathrm{C}$ for the collection of crude enzyme.

\section{Quantitative assay of extracellular hydrolytic enzymes}

The crude enzyme was assayed for hydrolytic enzymes based on the standard methods. The $\beta$-glucosidase (cellobiase; EC: 3.2.1.21) and $\beta$-xylosidase (EC: 3.2.1.37) activities were measured using $5 \mathrm{mM}$ of $p$-nitrophenyl$\beta$-D-glucopyranoside (pNPG) and $p$-nitrophenyl- $\beta$-Dxylopyranoside (pNPX) as a substrate, respectively. The quantitative assay of other hydrolytic enzymes, e.g. Filter paperase (FPase), endoglucanase (CMCase; EC: 3.2.1.4) and xylanase (EC: 3.2 .1 .8$)$ was performed spectrophotometrically by measuring the reducing sugar released by 
culture filtrate as a result of hydrolysis of Whatman No. 1 filter paper $(50 \mathrm{mg})$, carboxymethyl cellulose (CMC) $(2 \%$, $\mathrm{w} / \mathrm{v})$ and birch wood xylan $(1 \%, \mathrm{w} / \mathrm{v})$, respectively [16, 17]. The reducing sugar was estimated by DNSA method [18]. One unit of enzyme represents $1 \mu \mathrm{M}$ of end product released $\mathrm{mL}^{-1} \mathrm{~min}^{-1}$.

\section{Molecular identification and phylogenetic analysis of selected strains}

All isolates were identified using PCR amplification of $16 \mathrm{~S}$ ribosomal gene sequence based on molecular characterization technique. The overnight grown cultures were pelleted out and genomic DNA was isolated by using Zymo Research Fungal/Bacterial DNA MicroPrep $^{\text {TM }}$ kit. Partial 16S rRNA gene fragment of approximately $1.5 \mathrm{~kb}$ was amplified using universal PA (5' AGA GTT TGA TCC TGG CTC AG $3^{\prime}$ ) and PH (5' AAG GAG GTG ATC CAG CCG CA 3') primer set. The amplified PCR products were outsourced to Eurofins Genomics India Pvt Ltd., Bangalore, India, for DNA sequencing. The $16 \mathrm{~S}$ rRNA partial gene sequences of the isolates were compared by the NCBIBLAST search (http://www.ncbi.nlm.nih.gov) to identify the nearest taxa. The $16 \mathrm{~S}$ rRNA gene sequences were aligned for the construction of phylogenetic dendrogram. The tree topologies were calculated by bootstrap analysis of 1000 datasets using MEGA 5.0 software. The sequences were also submitted to NCBI Genbank.

\section{Selection of media components by using Taguchi experimental design}

The effect of different media components on $\beta$-glucosidase enzyme production by Bacillus subtilis RA10 was deduced by Taguchi optimization. The selected factors with their respective levels used for experiment are listed in Table 1. The design of experiment suggested a $\mathrm{L}_{25}\left(5^{5}\right)$ orthogonal array for the optimization, and totally 25 experiments were performed in triplicate with different combinations of five factors and respective five levels (Table 2). After experimentation, the data were analysed by analysis of variance (ANOVA) using Minitab ${ }^{\circledR}$ 16.2.1 software [19].
Optimization of selected media components by using BoxBehnken design

After the Taguchi-based optimization, Box-Behnken statistical method was chosen to optimize the concentrations of selected medium components. Therefore, medium components were chosen for optimizing their concentration for $\beta$-glucosidase enzyme production using B. subtilis RA10 (Table 3). The Design-Expert ${ }^{\circledR}$ Software was used for experiment design and analysis. A total of 27 experiments were conducted based on the design matrix with three centre points to minimize the experimental error (Table 4).

\section{Optimization of incubation temperature and time for $\beta$-glucosidase enzyme production}

The optimization of incubation temperature and time was performed for higher production of $\beta$-glucosidase enzyme from $B$. subtilis RA10. The enzyme was produced under optimized condition and extracted periodically up to $144 \mathrm{~h}$. The $\beta$-glucosidase production was evaluated at different temperatures within $5-60{ }^{\circ} \mathrm{C}$.

\section{$\beta$-Glucosidase production in bioreactor}

For large-scale production of $\beta$-glucosidase, B. subtilis RA10 was grown under optimized conditions in $7 \mathrm{~L}$ stirred tank bioreactor (Applikon, Schiedam, Netherlands) controlled by Applikon Bio Controller, Bio Console ADI1025. The bioreactor experiment was performed with automatic temperature control at $40{ }^{\circ} \mathrm{C}, 8.0 \mathrm{pH}$ and $200 \mathrm{rpm}$ of agitation rate. The dissolved oxygen was maintained at $70 \%$ by regulating the aeration of $1 \mathrm{~L} / \mathrm{min}$ with working volume of $5 \mathrm{~L}$. The $\mathrm{pH}$ was controlled by the automatic addition of either $5 \%(\mathrm{v} / \mathrm{v}) \mathrm{H}_{2} \mathrm{SO}_{4}$ or $5 \%$ $(\mathrm{v} / \mathrm{v}) \mathrm{NaOH}$. Overnight grown culture $\left(10^{5} \mathrm{CFU} / \mathrm{mL}\right)$ of B. subtilis RA10 in nutrient broth was used as primary inoculum. Samples were drawn periodically up to $96 \mathrm{~h}$. The crude enzyme was centrifuged at $10,000 \mathrm{~g}$ for $10 \mathrm{~min}$ and used for the assay of hydrolytic enzymes and protein content.

\section{Enzymatic saccharification of pretreated paddy straw} After optimization and characterization of $\beta$-glucosidase enzyme from B. subtilis RA10, the acetone-precipitated

Table 1 Factors and their levels employed in the Taguchi experimental design

\begin{tabular}{|c|c|c|c|c|c|c|c|}
\hline S. no. & Factor & Units & Level 1 & Level 2 & Level 3 & Level 4 & Level 5 \\
\hline 1 & Carbon source & $(1 \%, w / v)$ & Paddy straw & Wheat bran & Baggase & Wheat straw & Parthenium \\
\hline 2 & Organic N source & $(0.1 \%, w / v)$ & Yeast extract & Malt extract & Beef extract & Peptone & Tryptone \\
\hline 3 & $\mathrm{pH}$ & - & 6 & 7 & 8 & 9 & 10 \\
\hline 4 & Surfactant & $(0.1 \%, v / v)$ & Tween 20 & Tween 80 & Triton X 100 & PEG 6000 & - \\
\hline 5 & Inorganic N source & $(0.1 \%, w / v)$ & $\mathrm{NH}_{4} \mathrm{Cl}$ & $\mathrm{NaNO}_{3}$ & $\left(\mathrm{NH}_{4}\right)_{2} \mathrm{HPO}_{4}$ & $\mathrm{NH}_{4} \mathrm{NO}_{3}$ & $\left(\mathrm{NH}_{4}\right)_{2} \mathrm{SO}_{4}$ \\
\hline
\end{tabular}


Table 2 Design and experimental results of the $L_{25}\left(5^{5}\right)$ orthogonal array of Taguchi experimental design for $\beta$-glucosidase activity from $B$. subtilis RA10

\begin{tabular}{|c|c|c|c|c|c|c|}
\hline S. no. & Carbon source & Organic $\mathrm{N}$ source & $\mathrm{pH}$ & Surfactant & Inorganic N source & $\beta$-Glucosidase activity (IU/g) \\
\hline 1 & Paddy straw & Yeast extract & 6 & Tween 20 & $\mathrm{NH}_{4} \mathrm{Cl}$ & 25.00 \\
\hline 2 & Paddy straw & Malt extract & 7 & Tween 80 & $\mathrm{NaNO}_{3}$ & 32.37 \\
\hline 3 & Paddy straw & Beef extract & 8 & Triton X 100 & $\left(\mathrm{NH}_{4}\right)_{2} \mathrm{HPO}_{4}$ & 31.85 \\
\hline 4 & Paddy straw & Peptone & 9 & PEG 6000 & $\mathrm{NH}_{4} \mathrm{NO}_{3}$ & 32.77 \\
\hline 5 & Paddy straw & Tryptone & 10 & - & $\left(\mathrm{NH}_{4}\right)_{2} \mathrm{SO}_{4}$ & 21.32 \\
\hline 6 & Wheat bran & Yeast extract & 8 & Tween 80 & $\mathrm{NH}_{4} \mathrm{NO}_{3}$ & 25.74 \\
\hline 7 & Wheat bran & Malt extract & 9 & Triton $\times 100$ & $\left(\mathrm{NH}_{4}\right)_{2} \mathrm{SO}_{4}$ & 22.26 \\
\hline 8 & Wheat bran & Beef extract & 10 & PEG 6000 & $\mathrm{NH}_{4} \mathrm{Cl}$ & 19.37 \\
\hline 9 & Wheat bran & Peptone & 6 & - & $\mathrm{NaNO}_{3}$ & 17.4 \\
\hline 10 & Wheat bran & Tryptone & 7 & Tween 20 & $\left(\mathrm{NH}_{4}\right)_{2} \mathrm{HPO}_{4}$ & 21.32 \\
\hline 11 & Baggase & Yeast extract & 10 & Triton X 100 & $\mathrm{NaNO}_{3}$ & 26.47 \\
\hline 12 & Baggase & Malt extract & 6 & PEG 6000 & $\left(\mathrm{NH}_{4}\right)_{2} \mathrm{HPO}_{4}$ & 17.12 \\
\hline 13 & Baggase & Beef extract & 7 & - & $\mathrm{NH}_{4} \mathrm{NO}_{3}$ & 15.95 \\
\hline 14 & Baggase & Peptone & 8 & Tween 20 & $\left(\mathrm{NH}_{4}\right)_{2} \mathrm{SO}_{4}$ & 20.06 \\
\hline 15 & Baggase & Tryptone & 9 & Tween 80 & $\mathrm{NH}_{4} \mathrm{Cl}$ & 15.22 \\
\hline 16 & Wheat straw & Yeast extract & 7 & PEG 6000 & $\left(\mathrm{NH}_{4}\right)_{2} \mathrm{SO}_{4}$ & 22.38 \\
\hline 17 & Wheat straw & Malt extract & 8 & - & $\mathrm{NH}_{4} \mathrm{Cl}$ & 16.76 \\
\hline 18 & Wheat straw & Beef extract & 9 & Tween 20 & $\mathrm{NaNO}_{3}$ & 33.95 \\
\hline 19 & Wheat straw & Peptone & 10 & Tween 80 & $\left(\mathrm{NH}_{4}\right)_{2} \mathrm{HPO}_{4}$ & 27.02 \\
\hline 20 & Wheat straw & Tryptone & 6 & Triton X 100 & $\mathrm{NH}_{4} \mathrm{NO}_{3}$ & 21.82 \\
\hline 21 & Parthenium & Yeast extract & 9 & - & $\left(\mathrm{NH}_{4}\right)_{2} \mathrm{HPO}_{4}$ & 11.03 \\
\hline 22 & Parthenium & Malt extract & 10 & Tween 20 & $\mathrm{NH}_{4} \mathrm{NO}_{3}$ & 17.32 \\
\hline 23 & Parthenium & Beef extract & 6 & Tween 80 & $\left(\mathrm{NH}_{4}\right)_{2} \mathrm{SO}_{4}$ & 16.32 \\
\hline 24 & Parthenium & Peptone & 7 & Triton X 100 & $\mathrm{NH}_{4} \mathrm{Cl}$ & 19.63 \\
\hline 25 & Parthenium & Tryptone & 8 & PEG 6000 & $\mathrm{NaNO}_{3}$ & 15.82 \\
\hline
\end{tabular}

Table 3 Experimental range and coded levels employed in the response surface methodology (RSM) using the Box-Behnken design for increasing the production of $\beta$-glucosidase enzymes by $B$. subtilis RA10

\begin{tabular}{lllll}
\hline & Process variable & \multicolumn{3}{l}{ Range and level } \\
\cline { 3 - 5 } & & $\mathbf{- 1}$ & $\mathbf{0}$ & $\mathbf{+ 1}$ \\
\hline A & Paddy straw $(\%, w / v)$ & 1 & 2 & 3 \\
$B$ & Beef extract $(\%, w / v)$ & 0.1 & 0.25 & 0.4 \\
$C$ & PEG 6000 $(\%, v / v)$ & 0.1 & 0.25 & 0.4 \\
$D$ & $\mathrm{NaNO}_{3}(\%, \mathrm{w} / \mathrm{v})$ & 0.1 & 0.25 & 0.4 \\
\hline
\end{tabular}

crude extract was evaluated for the hydrolysis of pretreated paddy straw. The concentrate crude extract contained $\beta$-glucosidase $(78 \mathrm{IU} / \mathrm{mL})$, endoglucanase $(0.23 \mathrm{IU} / \mathrm{mL})$, FPase $(0.8 \mathrm{IU} / \mathrm{mL})$ and xylanase $(4.2 \mathrm{IU} /$ $\mathrm{mL}$ ) activities. Paddy straw was pretreated with sodium hydroxide as described by Tiwari et al. [20]. The composition of alkali pretreated paddy straw on a dry weight basis was $562 \mathrm{mg} / \mathrm{gds}$ of cellulose, $168 \mathrm{mg} / \mathrm{gds}$ of xylan and $81 \mathrm{mg} / \mathrm{gds}$ of lignin. Cellulase from Trichoderma reesei $\left(\right.$ Celluclast ${ }^{\circledR} 1.5 \mathrm{~L}$ ) was used as commercial cellulase enzyme preparation with FPase $(98.05 \mathrm{IU} / \mathrm{mL})$, CMCase (137.7 IU $/ \mathrm{mL}), \beta$-glucosidase (54.83 IU $/ \mathrm{mL}$ ) and xylanase $(152.5 \mathrm{IU} / \mathrm{mL})$. Enzymatic hydrolysis of alkali pretreated paddy straw was performed in four sets. Firstly, commercial cellulase (Celluclast $\left.{ }^{\circledR} 1.5 \mathrm{~L}\right)(30 \mathrm{FPU} / \mathrm{gds})$ and crude enzyme prepared from $B$. subtilis RA10 (15 $\beta$-glucosidase units/gds correspond to $0.15 \mathrm{FPU} / \mathrm{gds}$ ) were used separately for biomass hydrolysis. In another set, Celluclast ${ }^{\circledR}$ $1.5 \mathrm{~L}$ was supplemented with crude enzyme extract as a source of $\beta$-glucosidase produced by $B$. subtilis RA10. The fourth set of experiment was conducted to evaluate the effectiveness of FPU present in crude extract of $B$. subtilis. Thus, Celluclast ${ }^{\circledR} 1.5 \mathrm{~L}$ enzyme with $30.15 \mathrm{FPU} /$ gds was used for biomass hydrolysis. The saccharification of pretreated paddy straw was carried out in $50 \mathrm{mM}$ citrate buffer $(\mathrm{pH} 4.8)$ with $0.01 \%$ sodium azide at $5 \%$ substrate loading (dry weight basis). Experiments were performed at $50{ }^{\circ} \mathrm{C}$ under shaking condition $(150 \mathrm{rpm})$ for $72 \mathrm{~h}$. Samples were withdrawn periodically and analysed for sugar concentration by high-performance liquid 
Table 4 Box-Behnken design matrix for the experimental design and respective response for $\beta$-glucosidase activity from B. subtilis RA10

\begin{tabular}{|c|c|c|c|c|c|}
\hline \multirow[t]{2}{*}{ Std. order } & \multicolumn{4}{|c|}{ Experimental coded values of different variables } & \multirow{2}{*}{$\begin{array}{l}\beta \text {-Glucosidase activity (IU/g) } \\
\text { Actual }\end{array}$} \\
\hline & Paddy straw & Beef extract & PEG 6000 & $\mathrm{NaNO}_{3}$ & \\
\hline 1 & 1 & 0.1 & 0.25 & 0.25 & 37.67 \\
\hline 2 & 3 & 0.1 & 0.25 & 0.25 & 47.12 \\
\hline 3 & 1 & 0.4 & 0.25 & 0.25 & 30.41 \\
\hline 4 & 3 & 0.4 & 0.25 & 0.25 & 33.15 \\
\hline 5 & 2 & 0.25 & 0.1 & 0.1 & 36.48 \\
\hline 6 & 2 & 0.25 & 0.4 & 0.1 & 34.42 \\
\hline 7 & 2 & 0.25 & 0.1 & 0.4 & 42.97 \\
\hline 8 & 2 & 0.25 & 0.4 & 0.4 & 44.52 \\
\hline 9 & 1 & 0.25 & 0.25 & 0.1 & 36.85 \\
\hline 10 & 3 & 0.25 & 0.25 & 0.1 & 42.95 \\
\hline 11 & 1 & 0.25 & 0.25 & 0.4 & 46.64 \\
\hline 12 & 3 & 0.25 & 0.25 & 0.4 & 54.74 \\
\hline 13 & 2 & 0.1 & 0.1 & 0.25 & 37.33 \\
\hline 14 & 2 & 0.4 & 0.1 & 0.25 & 26.71 \\
\hline 15 & 2 & 0.1 & 0.4 & 0.25 & 35.57 \\
\hline 16 & 2 & 0.4 & 0.4 & 0.25 & 24.95 \\
\hline 17 & 1 & 0.25 & 0.1 & 0.25 & 38.72 \\
\hline 18 & 3 & 0.25 & 0.1 & 0.25 & 34.15 \\
\hline 19 & 1 & 0.25 & 0.4 & 0.25 & 27.29 \\
\hline 20 & 3 & 0.25 & 0.4 & 0.25 & 43.05 \\
\hline 21 & 2 & 0.1 & 0.25 & 0.1 & 41.42 \\
\hline 22 & 2 & 0.4 & 0.25 & 0.1 & 28.55 \\
\hline 23 & 2 & 0.1 & 0.25 & 0.4 & 48.96 \\
\hline 24 & 2 & 0.4 & 0.25 & 0.4 & 40.60 \\
\hline 25 & 2 & 0.25 & 0.25 & 0.25 & 37.03 \\
\hline 26 & 2 & 0.25 & 0.25 & 0.25 & 37.03 \\
\hline 27 & 2 & 0.25 & 0.25 & 0.25 & 37.03 \\
\hline
\end{tabular}

chromatography (Waters pump 515 model) equipped with Waters 2414 refractive index (RI) detector.

\section{Amplification of full length $\beta$-glucosidase gene}

The genomic DNA isolated from B. subtilis RA10 was used as a template to amplify $\beta$-glucosidase gene. A total of $100 \beta$-glucosidase protein sequences were retrieved from NCBI Genbank by selecting Firmicutes as organism group. All sequences were aligned using T-Coffee alignment (http://www.tcoffee.org/Projects/tcoffee). The degenerate primer set was designed for conserved amino acid sequence position 1-7 (MIHKKQG) and 473 to 478 (TNGKSL). The complete gene of $\beta$-glucosidase was amplified by degenerate primer set BGF $\left(5^{\prime}\right.$ GGC CGG ATC CAT GAT HCA YAA RAA RCA RGG I 3') and BGR (5' GGC CGT CGA CIA RIS WYT TIC CRT TIG T $3^{\prime}$ ) having BamHI restriction site (bold in forward primer) and SalI restriction site (bold in reverse primer).
The PCR amplification was conducted with Pfu DNA polymerase for high fidelity.

\section{Cloning and expression of $\beta$-glucosidase gene}

Amplified PCR product was cloned into pGEM-T easy vector (Promega, Wallisellen, Switzerland). The $\beta$-glucosidase gene was extracted from the positive clone with M13F and M13R primers and delivered for sequencing for conformation. $\beta$-glucosidase genes cloned into pGEM-T easy vector and $\mathrm{pET}^{28 \mathrm{a}^{+}}$(Novagen) were digested with BamHI and SalI restriction enzymes and run along with marker on $1 \%$ agarose gel. The ligated product was transformed into $E$. coli strain BL21 (DE3) competent cells.

\section{Purification of recombinant protein}

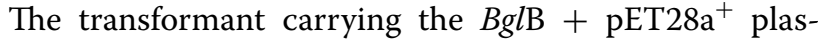
mid was grown up to $\log$ phase and expressed the 
recombinant protein as described previously. The cells were harvested by centrifugation at $6500 \mathrm{rpm}$ for $10 \mathrm{~min}$ and resuspended in buffer A $(50 \mathrm{mM}$ Tris- $\mathrm{HCl}$ and $200 \mathrm{mM} \mathrm{NaCl}, \mathrm{pH}$ 7.5). The cell suspension was sonicated $(6 \times 10 \mathrm{~s}$, Sonicator Heat system with $50 \%$ duty cycle) on ice and clear supernatant was collected for further purification. The overexpressed recombinant protein was purified by using electroelution technique. The soluble fraction of protein was run on two parallel native gels and after the completion of gel run, one gel was stained with Coomassie brilliant blue R-250 to visualize the overexpression. Thereafter, based on the location of overexpressed band, unstained gel was cut at the same site using a surgical blade. The gel slice was again chopped and transferred into the dialysis bag containing sodium citrate buffer $(0.05 \mathrm{M}, \mathrm{pH} 4.8)$. The dialysis bag was kept horizontally on agarose gel electrophoresis unit filled with sodium citrate buffer $(0.05 \mathrm{M}, \mathrm{pH} 4.8)$ and operated for $50 \mathrm{~V}$ for $1 \mathrm{~h}$. After the electrophoresis, the extract was analysed through $12 \%$ SDS-PAGE as described previously and stained with Coomassie brilliant blue R-250. The extract was further utilized for the characterization purpose.

\section{Characterization of purified recombinant protein}

The reaction velocity of the purified enzyme was determined using $0.5-5.0 \mathrm{mM} \quad p$-nitrophenyl- $\beta$-Dglucopyranoside in citrate buffer $(50 \mathrm{mM})$ of $\mathrm{pH}$ 5.0. The kinetic constants $K_{\mathrm{m}}$ and $k_{\text {cat }}$ were calculated by a nonlinear regression of Michaelis-Menten equation using GraphPad PRISM version 6.05 (trial version). The purified enzyme was further investigated to study the effect of temperature on $\beta$-glucosidase enzyme between 10 and $80{ }^{\circ} \mathrm{C}$. The optimal $\mathrm{pH}$ was analysed by estimating the activities between $\mathrm{pH} 3.0$ and 10.0 , using $50 \mathrm{mM}$ citrate ( $\mathrm{pH} 3.0-6.0)$, sodium phosphate $(\mathrm{pH} 6.0-9.0)$ and glycine- $\mathrm{NaOH}(\mathrm{pH} 9.0-10.0)$ buffers. The inhibitory effect of glucose on $\beta$-glucosidase activity was measured by adding different $\mathrm{D}$-glucose concentrations $(0-1000 \mathrm{mM})$. For the determination of temperature and $\mathrm{pH}$ stability, the enzyme was pre-incubated in the temperature range of $20,30,40,50,60$ and $80^{\circ} \mathrm{C}$ for $0-16 \mathrm{~h}$, or in the initial $\mathrm{pH}$ range $3-7$ at $30{ }^{\circ} \mathrm{C}$, and assayed for $\beta$-glucosidase activity.

\section{Sequence alignment, modelling and docking studies for full length amino acid sequence of BglB}

Full-length amino acid sequence of $B g l \mathrm{~B}$ was aligned with the other GH1 family $\beta$-glucosidase protein sequences by ClustalW. The homology model was also built using the automated SWISS-MODEL server, using $\beta$-glucosidase (PDB code 2XHY_A) as a template. The modelled structures were further verified by PROCHEK and Verify 3D.
The docking was carried out with AutoDock4 (http:// autodock.scripps.edu).

\section{Results \\ Isolation and identification of thermotolerant microorganisms}

The total viable count (TVC) of thermotolerant microbes ranged from $10^{3}$ to $10^{5} \mathrm{CFU}$ (colony forming unit)/g of sample. A total of 6 and 5 morphotypes were selected based on the colony morphology from compost and cow dung samples, respectively. Their capability to produce $\beta$-glucosidase enzyme was confirmed on the basis of the formation of dark brown zone on esculin plate at $40{ }^{\circ} \mathrm{C}$ (Additional file 1: Figure S1). For the identification of these bacterial isolates, the 16S rRNA gene was successfully amplified (about $1500 \mathrm{bp}$ ) from the eleven isolates. The isolates comprised seven different genera including Bacillus (Bacillus pumilus RA4, Bacillus cereus RA8, Bacillus thuringiensis RA9, Bacillus subtilis RA10), Arthrobacter (Arthrobacter nicotianae RA1, Arthrobacter sp. RA7), Exiguobacterium (Exiguobacterium acetylicum RA3), Kocuria (Kocuria rosea RA2), Ochrobactrum (Ochrobactrum intermedium RA5), Streptomyces (Streptomyces sp. RA6) and Alcaligenes (Alcaligenes faecalis RA11) (Table 5). All these isolates lie in four different phyla including Actinobacteria, Firmicute, $\alpha$-Proteobacteria and $\beta$-Proteobacteria. The phylogenetic relationship of each thermotolerant isolate with their respective nearest neighbour is presented in Fig. 1.

\section{Evaluation of selected isolates for $\beta$-glucosidase enzyme production using saccharides as carbon source}

All the thermotolerant isolates obtained from compost and cow dung were able to grow and produce $\beta$-glucosidase enzyme at 30,40 and $50{ }^{\circ} \mathrm{C}$. Of all isolates, $B$. subtilis RA10 produced maximum $\beta$-glucosidase enzyme $(3.19 \pm 0.13 \mathrm{IU} / \mathrm{g})$ at $40{ }^{\circ} \mathrm{C}$ by using cellobiose as carbon source (Fig. 2) which was selected for further optimization studies.

\section{Effect of different media components on $\beta$-glucosidase enzyme production by $B$. subtilis RA10}

$\beta$-Glucosidase enzyme production by thermotolerant B. subtilis RA10 was optimized by Taguchi design. The experimental run gave $\beta$-glucosidase enzyme production ranging from 11.03 to $33.95 \mathrm{IU} / \mathrm{g}$ (Table 2). The ANOVA table indicated that all the factors play a significant $(P<0.05)$ role in the enzyme production. The significance of model was revealed by $97 \%$ of coefficient of variation $\left(R^{2}\right)$ (Table 6). On the basis of contribution percentage, carbon source was examined as the most influential factor with $52.12 \%$ contribution followed by surfactant $(22.05 \%)$ and inorganic $\mathrm{N}$ source (11.45\%). Other factors 
Table 5 Description and phylogenetic affiliation of selected isolates from compost (CM) and cow dung (CD)

\begin{tabular}{|c|c|c|c|c|c|c|c|c|}
\hline S. no. & Isolate & $\begin{array}{l}\text { Sample } \\
\text { type }\end{array}$ & Gram stain & $\begin{array}{l}\text { Colony } \\
\text { colour }\end{array}$ & Division & Most similar neighbour & Identity (\%) & $\begin{array}{l}\text { GenBank } \\
\text { accession number }\end{array}$ \\
\hline 1 & RA1 & CM & Positive & White & Actinomycetales & Arthrobacter nicotianae & 98 & KT898113 \\
\hline 2 & RA2 & CM & Positive & White & Actinomycetales & Kocuria rosea & 99 & KT898114 \\
\hline 3 & RA3 & $C D$ & Positive & Orange & Firmicute & $\begin{array}{l}\text { Exiguobacterium acetyli- } \\
\text { cum }\end{array}$ & 99 & KT898115 \\
\hline 4 & RA4 & CD & Positive & White & Firmicute & Bacillus pumilus & 98 & KT898116 \\
\hline 5 & RA5 & CD & Negative & Cream & a-Proteobacteria & $\begin{array}{l}\text { Ochrobactrum interme- } \\
\text { dium }\end{array}$ & 99 & KT898117 \\
\hline 6 & RA6 & $C D$ & Positive & White & Actinomycetales & Streptomyces sp. & 99 & KT898118 \\
\hline 7 & RA7 & CM & Positive & White & Actinomycetales & Arthrobacter sp. & 99 & KT898119 \\
\hline 8 & RA8 & CM & Positive & White & Firmicute & Bacillus cereus & 98 & KT898120 \\
\hline 9 & RA9 & $C D$ & Positive & White & Firmicute & Bacillus thuringiensis & 99 & KT898121 \\
\hline 10 & RA10 & CM & Positive & White & Firmicute & Bacillus subtilis & 99 & KT898122 \\
\hline 11 & RA11 & CM & Negative & White & $\beta$-Proteobacteria & Alcaligenes faecalis & 98 & KT898123 \\
\hline
\end{tabular}

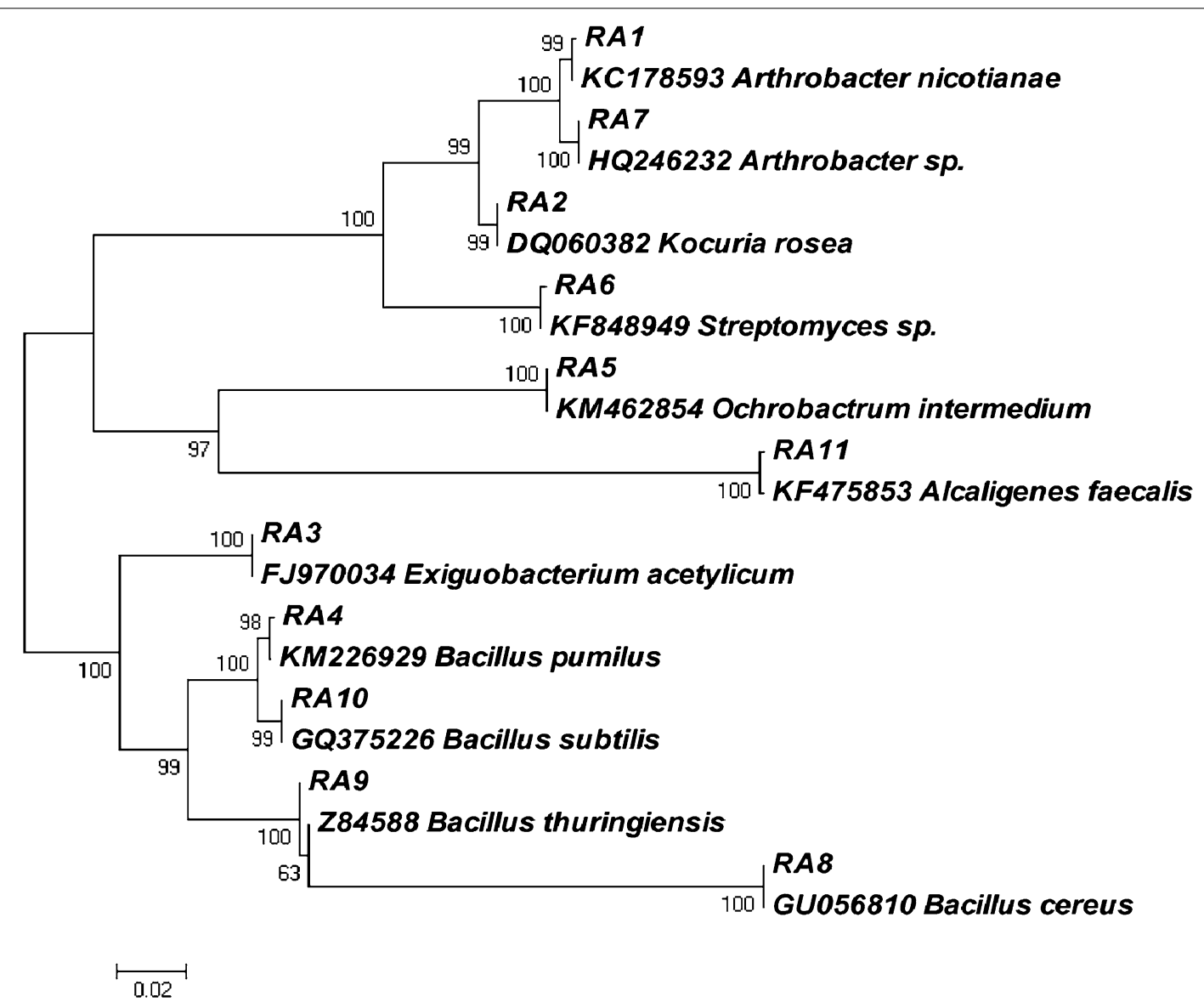

Fig. 1 Phylogenetic trees based on ribosomal gene sequences showing the relationship of all strains obtained from compost and cow dung with their nearest phylogenetic relatives 


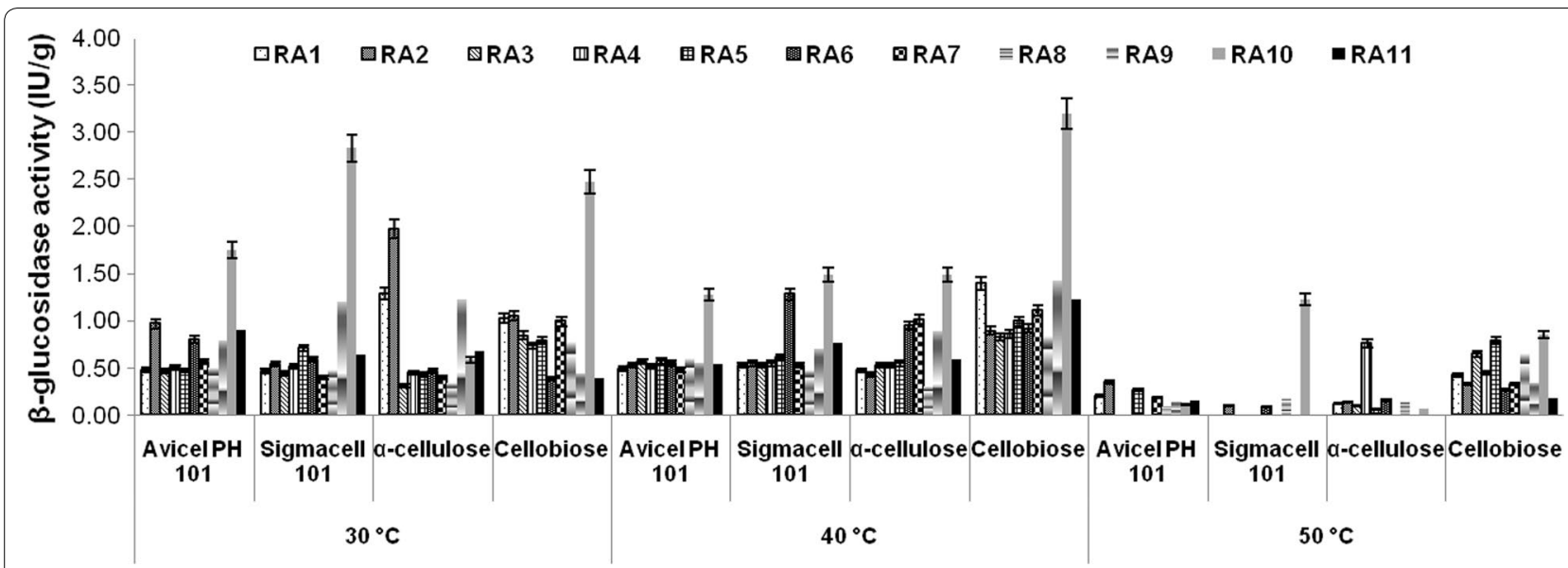

Fig. 2 Effect of different carbon sources on the production of $\beta$-glucosidase by selected isolates from compost and cow dung at different temperatures

Table 6 Analysis of variance (ANOVA) of $\beta$-glucosidase enzyme production by B. subtilis RA10 by using Minitab 16 software based on $\mathrm{L}_{25}\left(5^{5}\right)$ standard orthogonal array experiment

\begin{tabular}{|c|c|c|c|c|c|c|c|c|}
\hline S. no. & Factors & DOF & Sum of squares & Variance & $F$ value & $P$ value & Contribution (\%) & Rank \\
\hline 1 & Carbon source & 4 & 477.527 & 119.382 & 16.04 & 0.00 & 52.12 & 1 \\
\hline 2 & Organic N source & 4 & 65.586 & 16.396 & 2.2 & 0.00 & 7.16 & 4 \\
\hline 3 & Surfactant & 4 & 201.971 & 50.493 & 6.78 & 0.00 & 22.05 & 2 \\
\hline 4 & $\mathrm{pH}$ & 4 & 36.374 & 9.094 & 1.22 & 0.00 & 3.97 & 5 \\
\hline \multirow[t]{3}{*}{5} & Inorganic N source & 4 & 104.898 & 26.224 & 3.52 & 0.00 & 11.45 & 3 \\
\hline & Error & 54 & 29.78 & 7.445 & & & 3.25 & \\
\hline & Total & 74 & 916.135 & & & & 100.00 & \\
\hline
\end{tabular}

$S=2.72854, R^{2}=0.97, R^{2}(\mathrm{adj})=0.93$

also showed significant effect on enzyme production. The validation experiment confirms that paddy straw as carbon source, beef extract and $\mathrm{NaNO}_{3}$ as organic and inorganic $\mathrm{N}$ source, PEG 6000 as surfactant and $\mathrm{pH} 8$ were the optimum medium component for maximizing the $\beta$-glucosidase enzyme production $(36.64 \pm 0.28 \mathrm{IU} / \mathrm{g})$ by $B$. subtilis RA10. After optimization by using Taguchi design, the $\beta$-glucosidase enzyme production was 11.5 fold higher as compared with previous experiment under unoptimized condition.

\section{Optimization of the concentration of selected medium component using RSM}

$\beta$-Glucosidase enzyme production by $B$. subtilis RA10 was optimized by Box-Behnken design to evaluate the interaction between different independent variables and their levels. Based on Taguchi optimization, four selected medium components, namely, $(A)$ paddy straw, $(B)$ beef extract, $(C)$ PEG 6000 and $(D) \mathrm{NaNO}_{3}$ were further investigated for their optimum combination using RSM following Box-Behnken design matrix.
The experimental data of $\beta$-glucosidase enzyme production by B. subtilis RA10 are mentioned in Table 4. Four selected factors includes Paddy straw $(1-3 \%(\mathrm{w} / \mathrm{v}))$, Beef extract $(0.1-0.4 \%(\mathrm{w} / \mathrm{v}))$, PEG $6000(0.1-0.4 \%(\mathrm{w} / \mathrm{v}))$ and $\mathrm{NaNO}_{3}(0.1-0.4 \%(\mathrm{w} / \mathrm{v}))$. The results obtained after BoxBehnken design were subjected to ANOVA (Table 7) and fitted with the polynomial equation. Based on quadratic model of response, the equation in terms of coded variable and actual variables was as follows:

$$
\begin{aligned}
\beta \text {-Glucosidase }= & +37.03+3.13 * A-5.31 * B-0.55 * C \\
& +4.81 * D-1.68 * A * B+5.08 * A * C \\
& +0.50 * A * D+0.00 * B * C+1.13 * B * D . \\
& +0.90 * C * D+2.44 * A^{2}-2.59 * B^{2} \\
& -3.38 * C^{2}+5.74 * D^{2}
\end{aligned}
$$

The quadratic type model was produced and all the effects were found to be significant $(P<0.05)$. Among six interactions, two [paddy straw/ $\mathrm{NaNO}_{3}(A D)$ and Beef extract/PEG $6000(B C)$ ] displayed insignificant $P$ value $(P>0.05)$ and therefore suggested insignificant 
Table 7 Regression analysis for the production of $\beta$-glucosidase enzyme from $B$. subtilis RA 10 for quadratic response surface model fitting (ANOVA)

\begin{tabular}{lrrlrr}
\hline Source & Sum of squares & $\boldsymbol{d f}$ & Mean square & $\boldsymbol{F}$ value & $\begin{array}{l}\boldsymbol{P} \text { value } \\
\text { Prob }>\boldsymbol{F}\end{array}$ \\
\hline Model & 1311.03 & 14 & 93.64 & 170.69 & $<0.0001$ \\
A paddy straw & 117.65 & 1 & 117.65 & 214.45 & $<0.0001$ \\
B beef extract & 338.07 & 1 & 338.07 & 616.22 & $<0.0001$ \\
CPEG 6000 & 3.57 & 1 & 3.57 & 6.507 & 0.0254 \\
$D$ NaNO${ }_{3}$ & 277.96 & 1 & 277.96 & 506.65 & $<0.0001$ \\
$A B$ & 11.24 & 1 & 11.24 & 20.48 & 0.0007 \\
$A C$ & 103.34 & 1 & 103.34 & 188.36 & $<0.0001$ \\
$A D$ & 1.00 & 1 & 1.00 & 1.82 & 0.2019 \\
$B C$ & 0.00 & 1 & 0.00 & 0 & 1.0000 \\
$B D$ & 5.10 & 1 & 5.10 & 9.28 & 0.0101 \\
$C D$ & 3.25 & 1 & 3.25 & 5.92 & 0.0315 \\
$A^{2}$ & 31.86 & 1 & 31.86 & 58.06 & $<0.0001$ \\
$B^{2}$ & 35.85 & 1 & 35.85 & 65.34 & $<0.0001$ \\
$C^{2}$ & 60.89 & 1 & 60.89 & 110.99 & $<0.0001$ \\
$D^{2}$ & 175.65 & 1 & 175.65 & 320.17 & $<0.0001$ \\
Residual & 6.58 & 12 & 0.548615 & & 0.08 \\
Lack of fit & 6.58 & 10 & 0.658337 & & Not significant \\
Pure error & 0.00 & 2 & 0 & & \\
\hline
\end{tabular}

interaction effect on $\beta$-glucosidase production. The rest of the four interactions between beef extract/paddy straw, $\mathrm{NaNO}_{3} /$ beef extract, PEG 6000/paddy straw and $\mathrm{NaNO}_{3} /$ PEG 6000 displayed that their effect on $\beta$-glucosidase production was significant but not linear. The interactive effect of factors on $\beta$-glucosidase production was also analysed by $3 \mathrm{D}$ contour plots against two experimental factors (Fig. 3).
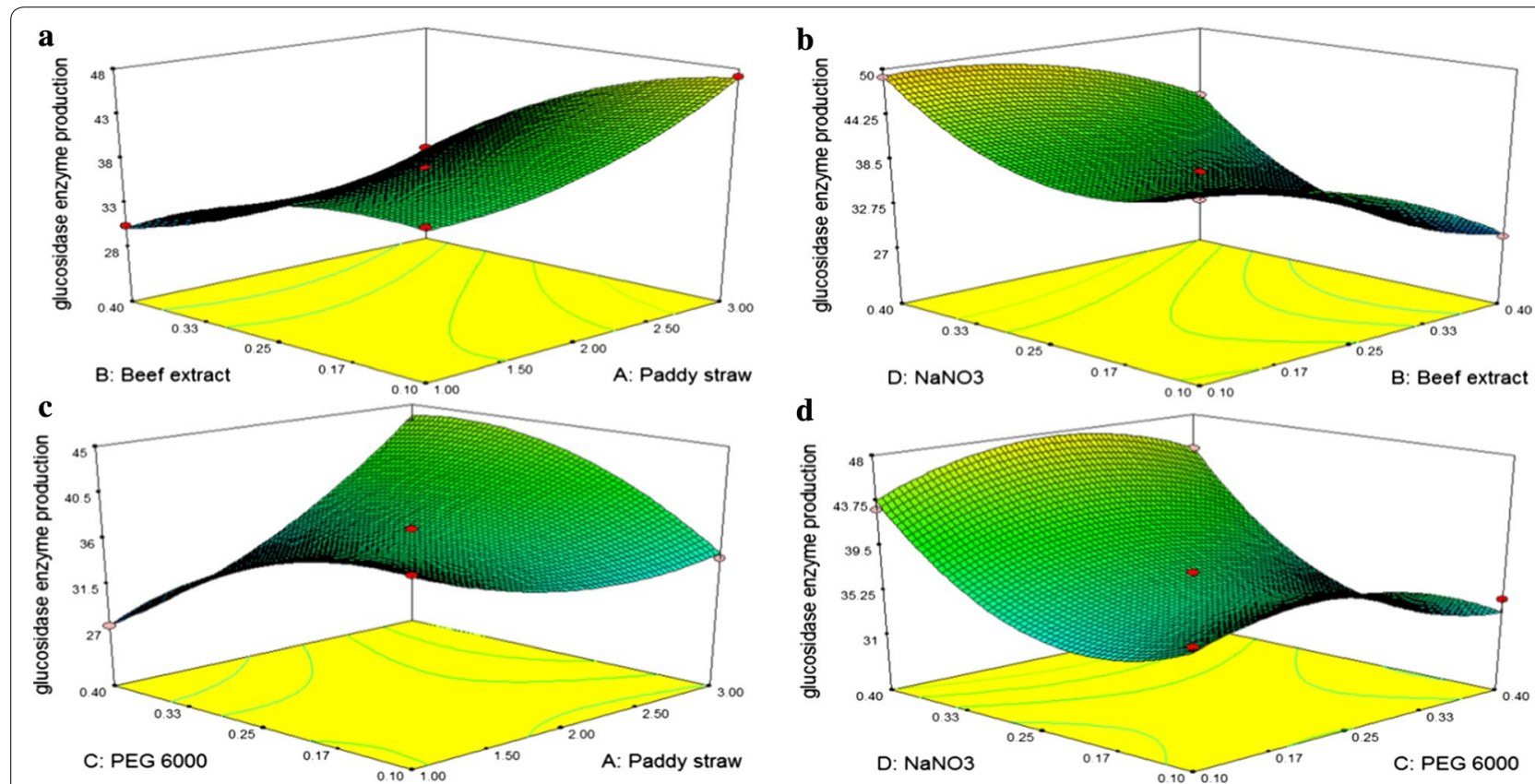

d

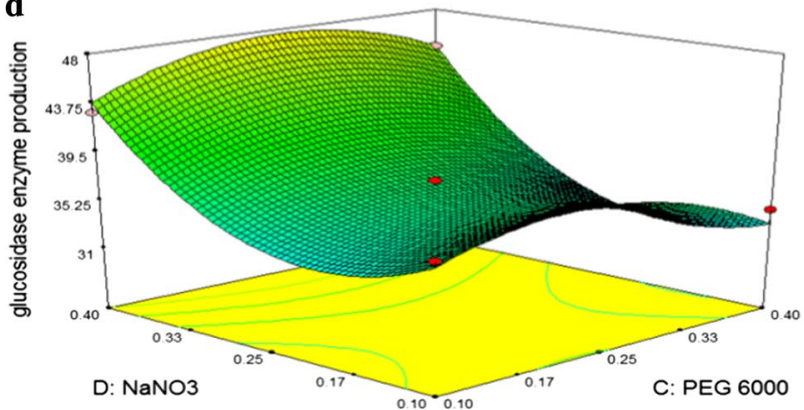

Fig. 3 Response surface plots of Box-Behnken design for optimization of the $\beta$-glucosidase enzyme production by B. subtilis RA10. Figure shows the interaction between a beef extract and Paddy straw, b NaNO 3 and beef extract, c PEG 6000 and paddy straw, d NaNO 3 and PEG 6000 
The developed model was validated by performing the experiment under predicted optimal condition for maximizing the $\beta$-glucosidase enzyme production by $B$. subtilis RA10. The model proposed paddy straw $-1.24 \%(\mathrm{w} / \mathrm{v})$, beef extract-0.29\% (w/v), PEG 6000-0.14\% (v/v) and $\mathrm{NaNO}_{3}-0.12 \%(\mathrm{w} / \mathrm{v})$ as the optimum conditions with predicted $\beta$-glucosidase yield of $55.21 \mathrm{IU} / \mathrm{g}$. The experimental $\beta$-glucosidase activity $57.31 \pm 0.81 \mathrm{IU} / \mathrm{g}$ under optimized condition was in close agreement with the predicated $\beta$-glucosidase activity. After Box-Behnken design-based optimization, $\beta$-glucosidase enzyme production increased by 1.6 -fold as compared to the result obtained after Taguchi optimization $(36.64 \pm 0.28 \mathrm{IU} / \mathrm{g})$.

\section{Effect of incubation temperature and time on production of $\beta$-glucosidase enzyme by $B$. subtilis RA10}

After the statistical optimization by Taguchi experiment and Box-Behnken design, the effect of incubation temperature and time on production of $\beta$-glucosidase enzyme was observed. B. subtilis RA10 produced $\beta$-glucosidase enzyme at broad range of incubation temperature ranging from 30 to $60{ }^{\circ} \mathrm{C}$ with the activity ranging between $31.94 \pm 0.48$ and $58.71 \pm 1.73 \mathrm{IU} / \mathrm{g}$ (Fig. 4). The maximum $\beta$-glucosidase enzyme production $(58.71 \pm 1.73 \mathrm{IU} / \mathrm{g})$ was achieved at $40{ }^{\circ} \mathrm{C}$ after $72 \mathrm{~h}$ of Incubation, and further incubation up to $144 \mathrm{~h}$ did not result in any increase in enzyme activity.

\section{$\beta$-Glucosidase production in bioreactor by $B$. subtilis RA10}

For large-scale $\beta$-glucosidase production, thermotolerant B. subtilis RA10 was grown under the optimized medium condition with $1.24 \%(\mathrm{w} / \mathrm{v})$ of paddy straw, $0.29 \%(\mathrm{w} / \mathrm{v})$ of beef extract, $0.14 \%(\mathrm{v} / \mathrm{v})$ of PEG 6000 and $\mathrm{NaNO}_{3}-0.12 \%(\mathrm{w} / \mathrm{v})$ at $40{ }^{\circ} \mathrm{C}$. The bacterial growth increased throughout the experiment and the population reached $12 \times 10^{8} \mathrm{CFU} / \mathrm{mL}$ in liquid medium after $96 \mathrm{~h}$

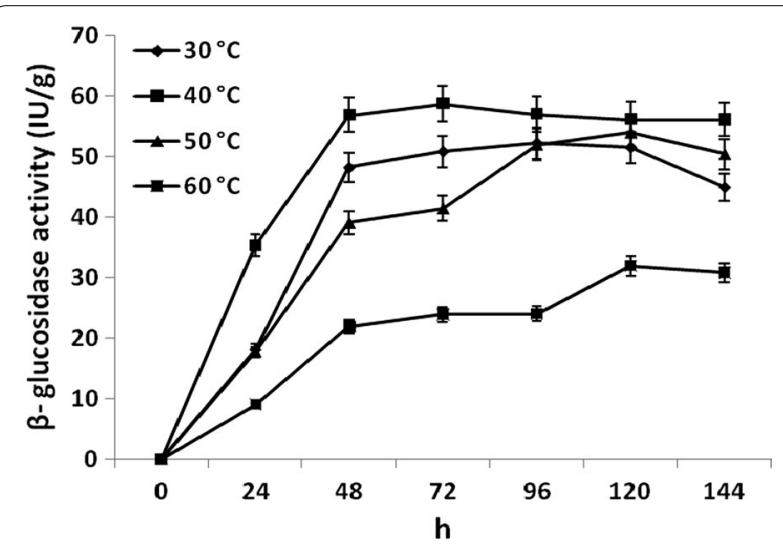

Fig. 4 Effect of incubation temperature and time on the production of $\beta$-glucosidase enzyme from $B$. subtilis RA10 during submerged fermentation in flask of submerged fermentation. The extracellular protein also reached from $0.11 \pm 0.03$ to $0.42 \pm 0.04 \mathrm{mg} / \mathrm{mL}$. The maximum $\beta$-glucosidase yield of $63.29 \pm 1.73 \mathrm{IU} / \mathrm{g}$ was achieved after $80 \mathrm{~h}$ of incubation which was 1.08 -fold higher than the shake flask experiment. Thermotolerant B. subtilis RA10 also co-produced other hydrolytic enzymes like endoglucanase $(11.04 \pm 0.24 \mathrm{IU} / \mathrm{g})$, FPase $(12.00 \pm 0.47 \mathrm{IU} / \mathrm{g})$, xylanase $(20.81 \pm 0.38 \mathrm{IU} / \mathrm{g})$ and $\beta$-xylosidase $(31.32 \pm 0.99 \mathrm{IU} / \mathrm{g})$ after $96 \mathrm{~h}$ of incubation (Fig. 5).

\section{Saccharification of pretreated paddy straw by supplementing $\beta$-glucosidase enzyme from $B$. subtilis RA10}

$\beta$-Glucosidase producing B. subtilis RA10 secretome was further evaluated for saccharification of alkali-pretreated paddy straw at $50{ }^{\circ} \mathrm{C}$. This experiment was performed in three different sets: crude secretome of B. subtilis RA10; commercial cellulase (Celluclast ${ }^{\circledR} 1.5 \mathrm{~L}$ ) and Celluclast ${ }^{\circledR} 1.5 \mathrm{~L}$ supplemented with crude secretome of B. subtilis RA10 as a source of indigenous $\beta$-glucosidase, for saccharification of alkali-pretreated paddy straw (Table 8). Initially, saccharification experiment was performed by crude secretome of $B$. subtilis RA10 alone, and small amount of glucose $(45.34 \pm 0.73 \mathrm{mg} / \mathrm{gds})$ and xylose $(8.84 \pm 0.10 \mathrm{mg} / \mathrm{gds})$ was released after $48 \mathrm{~h}$ of saccharification process. In another set, saccharification of pretreated paddy straw with commercial cellulase (Celluclast ${ }^{\circledR} 1.5 \mathrm{~L}$ ) was performed and higher sugar release (437.79 $\pm 3.54 \mathrm{mg} / \mathrm{gds})$ was observed. In third set of experiment, the supplementation of $\beta$-glucosidase with Celluclast ${ }^{\circledR} 1.5 \mathrm{~L}$ significantly improved the release of total sugars $(582.58 \pm 2.22 \mathrm{mg} / \mathrm{gds})$ from the alkali pretreated paddy straw which was 1.33-fold higher than the sugar release obtained from the commercial cellulase alone. The effect of supplementation of $\beta$-glucosidase from $B$. subtilis RA10 into commercial Celluclast ${ }^{\circledR} 1.5 \mathrm{~L}$ was observed as the glucose release after the supplementation was 1.34-fold higher. In fourth set, $30.15 \mathrm{FPU} /$ gds commercial cellulase (Celluclast ${ }^{\circledR} 1.5 \mathrm{~L}$ ) was found to release $447.2 \pm 1.94 \mathrm{mg} / \mathrm{gds}$ of total sugar which was comparable with second set of saccharification experiment.

PCR amplification, cloning and overexpression of BgIB in $E$. coli BL21 (DE3)

The amplified product of full length $B g l \mathrm{~B}$ gene (1437 bp) was cloned in pGEM-T Easy vector and the ligated product was transformed into E. coli (DH5 $\alpha$ ) strain (Additional file 1: Figure S2). The positive white clone was selected and insert was validated by amplifying the insert by M13 primers. Upon digestion of the recombinant vector pGEM-T $+B g l \mathrm{~B}$ with BamHI and SalI restriction 


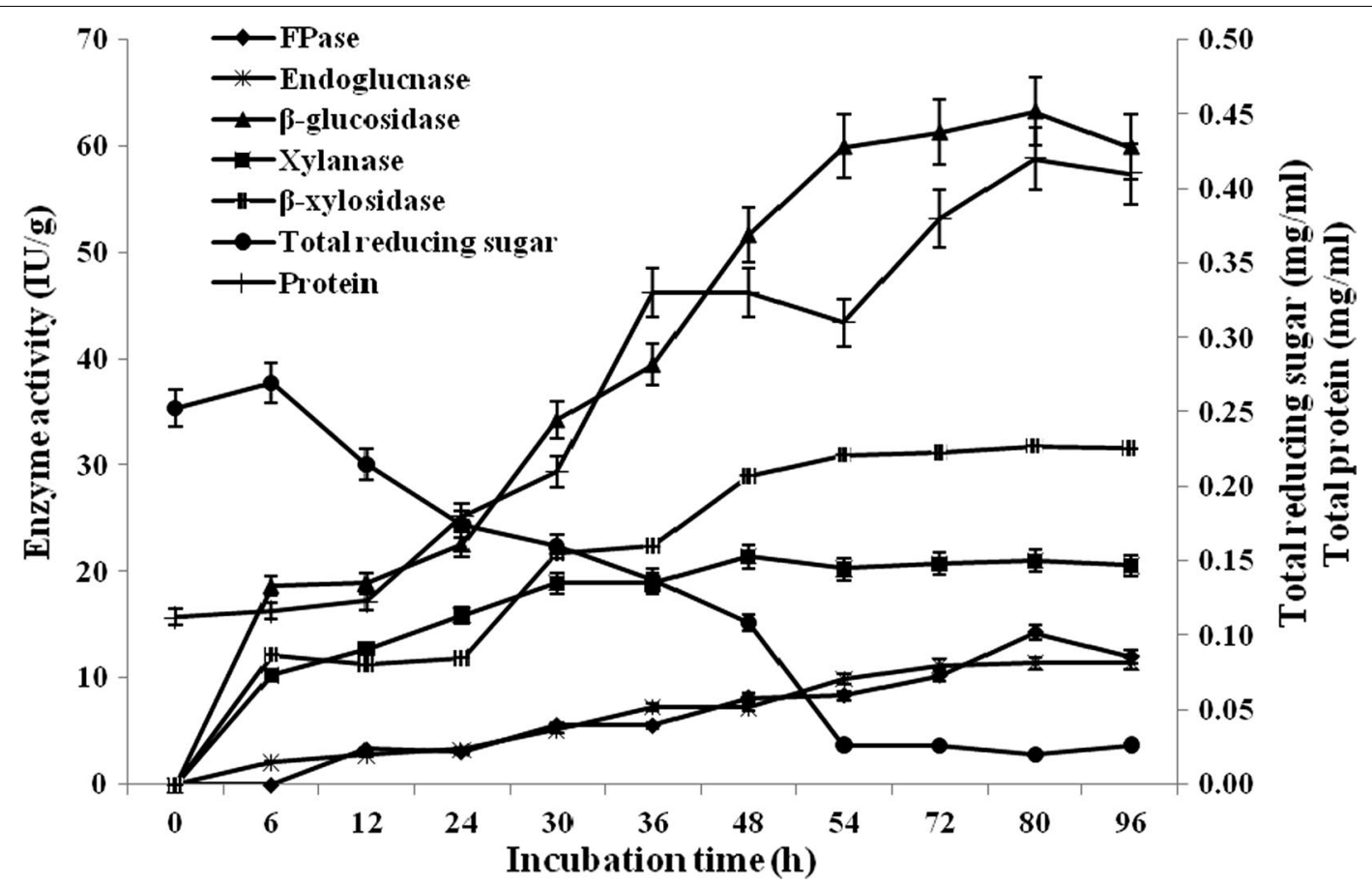

Fig. 5 Profile of hydrolytic enzyme production by B. subtilis RA10 under optimized condition in $7 \mathrm{~L}$ fermentor

Table 8 Sugar release after 72-h saccharification of alkali-pretreated paddy straw by cellulase from T. reesei ATCC 26921 (Celluclast ${ }^{\circledR} 1.5 \mathrm{~L}$ ) supplemented with $\beta$-glucosidase from $B$. subtilis RA10

\begin{tabular}{|c|c|c|c|c|}
\hline \multirow[t]{2}{*}{ S. no. } & \multirow[t]{2}{*}{ Enzyme loading } & \multicolumn{3}{|c|}{ Sugar release (mg/gds) } \\
\hline & & Glucose & Xylose & Total sugar \\
\hline 1 & $\beta$-Glucosidase from B. subtilis RA10 (15 $\beta$-glucosidase unit/gds corresponds to $0.15 \mathrm{FPU} / \mathrm{gds}$ ) & $45.34 \pm 0.73$ & $8.84 \pm 0.10$ & $54.18 \pm 0.83$ \\
\hline 2 & Celluclast $^{\circledR} 1.5 \mathrm{~L}(30 \mathrm{FPU} / \mathrm{gds})$ & $376.14 \pm 2.36$ & $61.65 \pm 1.18$ & $437.79 \pm 3.54$ \\
\hline 3 & $\begin{array}{l}\text { Celluclast }{ }^{\circledR} 1.5 \mathrm{~L} \text { (30 FPU/gds) supplemented with } \beta \text {-glucosidase (15 unit/gds) from B. subtilis } \\
\text { RA10 }\end{array}$ & $506.16 \pm 1.74$ & $76.42 \pm 0.48$ & $582.58 \pm 2.22$ \\
\hline 4 & Celluclast $^{\circledR} 1.5 \mathrm{~L}(30+0.15=30.15 \mathrm{FPU} / \mathrm{gds})$ & $384.38 \pm 1.06$ & $62.82 \pm 0.88$ & $447.2 \pm 1.94$ \\
\hline
\end{tabular}

enzymes, the released fragments were obtained for further subcloning. For the expression of $B g l \mathrm{~B}$ in $E$. coli, the ORF was cloned in $\mathrm{pET} 28 \mathrm{a}^{+}$expression vector. The

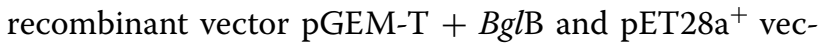
tor was double digested with BamHI and SalI for directional cloning. The plasmid was isolated from these clones and digested with BamHI and SalI, which showed the presence of $B g l \mathrm{~B}$ gene. A positive clone was then chosen for expression studies.

Cloned $\beta$-glucosidase gene $B g l \mathrm{~B}$ was overexpressed under the control of IPTG-inducible phage T7 promotor, which is predicted to encode a recombinant protein of 497 amino acids with a molecular weight of $~ 57.13 \mathrm{kDa}$. On analysis of protein on $12 \%$
SDS-PAGE, correct size recombinant protein band ( $\sim 57.13 \mathrm{kDa})$ was observed. The results confirmed that the ORF was selectively expressed in the transformed $E$. coli BL21 (DE3) cells and apparently constituted a large fraction of the total protein. The overexpressed protein was purified by electroelution. The purified protein ( $\sim 57.13 \mathrm{kDa}$ ) was also confirmed by SDS-PAGE (Fig. 6). The $\beta$-glucosidase enzyme activity was also measured in the soluble fraction and purified protein. The soluble fraction of the $\beta$-glucosidase enzyme activity was $7.83 \pm 0.21 \mathrm{IU} / \mathrm{mL}$ with $13.50 \pm 0.93 \mathrm{IU} / \mathrm{mg}$ of specific activity, while purified enzyme showed the enzyme activity of $5.27 \pm 0.78 \mathrm{IU} / \mathrm{mL}$ with higher specific activity $47.91 \pm 1.43 \mathrm{IU} / \mathrm{mg}$. 


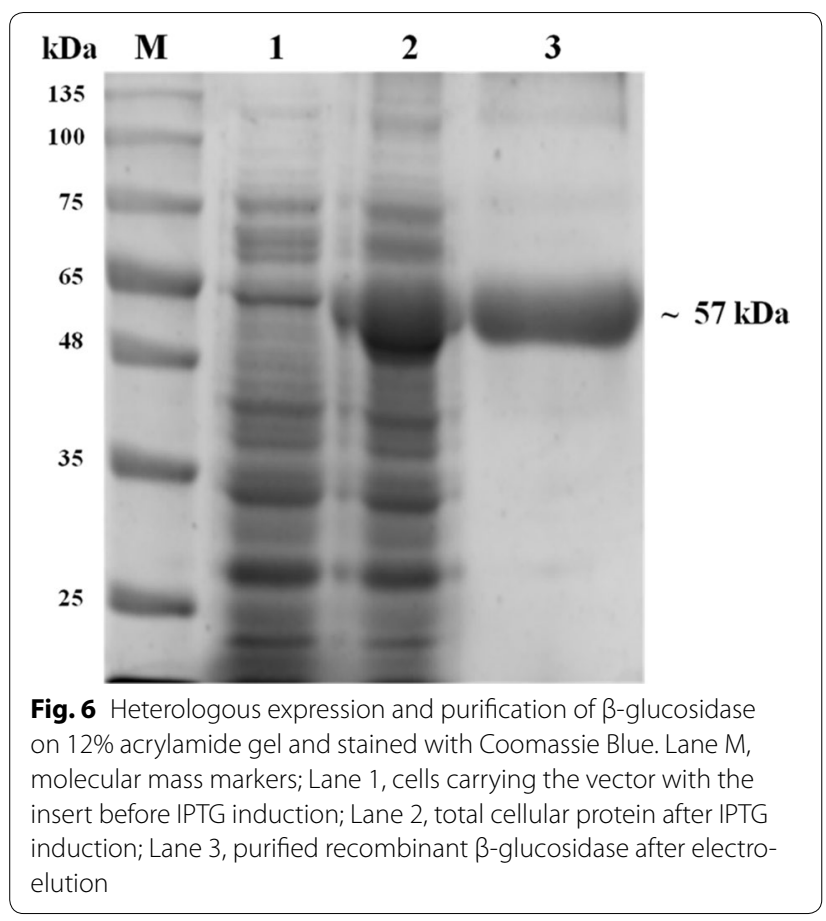

\section{Kinetic parameters of BglB $\beta$-glucosidase enzymes}

The purified protein obtained from previous experiment was also used to determine the enzyme kinetics by using $p$ NPG as a substrate (Additional file 1: Figure S3). The $K_{\mathrm{m}}$ and $k_{\text {cat }}$ of the $\beta$-glucosidase enzyme were found to be $3.90 \pm 0.20 \mathrm{mM}$ and $3.09 \pm 0.02 \mathrm{~s}^{-1}$, respectively. The $V_{\max }$ was achieved as $12.05 \pm 0.32 \mu \mathrm{M} / \mathrm{min}$.

\section{Optimum temperature, $\mathrm{pH}$ and glucose for $\beta$-glucosidase enzyme}

To characterize the $\beta$-glucosidase enzyme for optimum $\mathrm{pH}$ and temperature, the activity of enzyme was measured at different temperatures $\left(30-80{ }^{\circ} \mathrm{C}\right)$ and $\mathrm{pH}$ ranges (3.0-10.0). The purified enzyme retained $78 \%$ of $\beta$-glucosidase activity at $80{ }^{\circ} \mathrm{C}$ of temperature (Fig. 7a). The enzyme also retained $70 \%$ activity at alkaline $\mathrm{pH} 7.0$ (Fig. 7b). The glucose inhibition studies showed very less effect of high glucose concentration on $\beta$-glucosidase activity. Purified $\beta$-glucosidase retained $70 \%$ of activity in the presence of $1000 \mathrm{mM}$ of glucose concentration (Fig. 7c). $\beta$-glucosidase activity was checked for thermal stability at temperature range of $30-80{ }^{\circ} \mathrm{C}$ (Fig. 8). The enzyme remained active in a wide range of temperatures with highest activity $(68.32 \%)$ at $50{ }^{\circ} \mathrm{C}$ after $48 \mathrm{~h}$ of incubation. However, $\beta$-glucosidase enzyme also retained $52.92,40.42$ and $17.55 \%$ of their activity at 60,70 and $80{ }^{\circ} \mathrm{C}$, respectively, after $48 \mathrm{~h}$ of incubation.

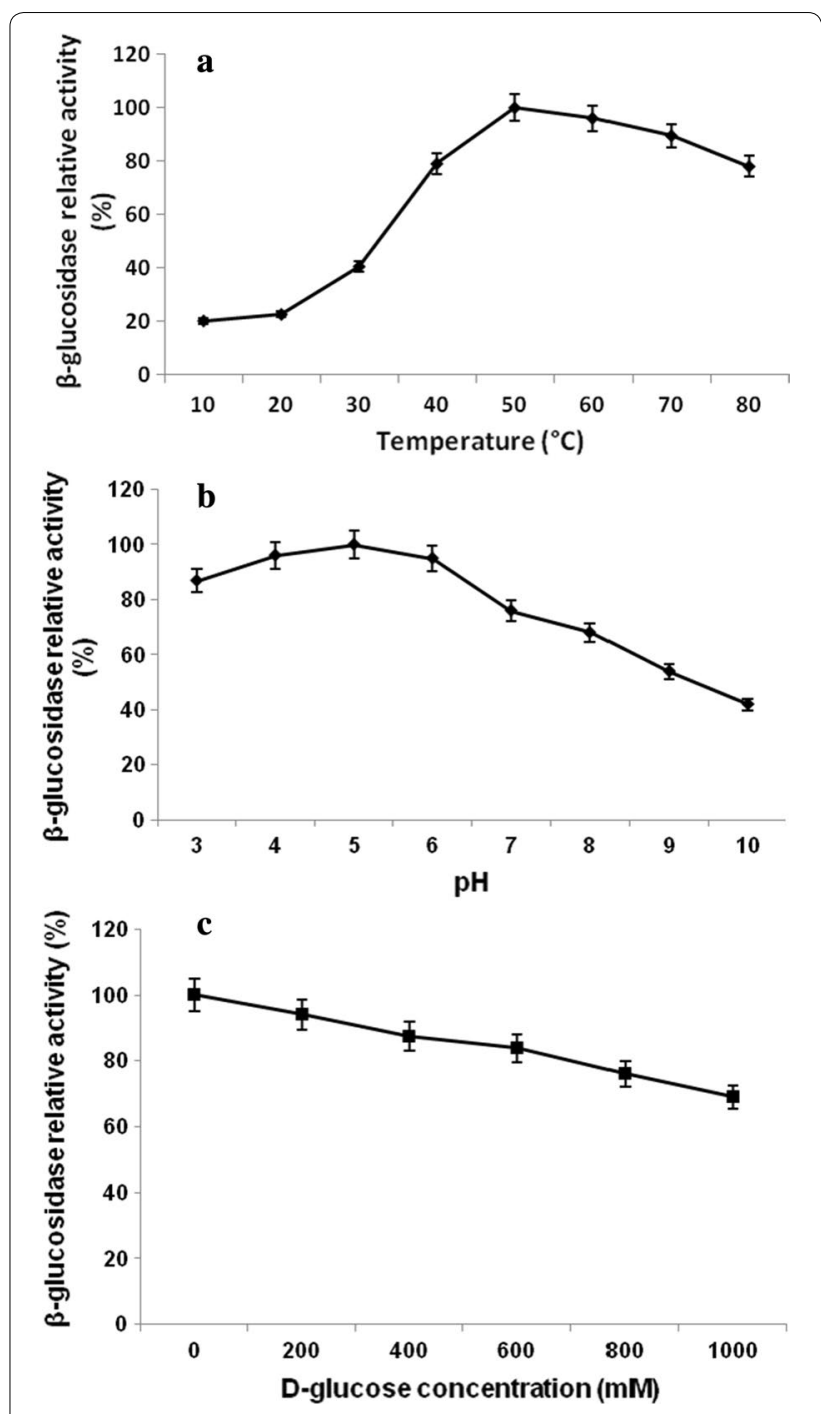

Fig. 7 Effect of temperature (a), $\mathrm{pH}(\mathbf{b})$ and glucose concentration (c) on the purified $\beta$-glucosidase activity from B. subtilis RA10

Sequence alignment, modelling and docking studies

The cloned $B g l \mathrm{~B}$ gene was also sequenced, and deduced amino acid sequence was matched with the available GenBank database. The BLAST analysis showed highest identity (98\%) with $\beta$-glucosidase from Bacillus amyloliquefaciens (NCBI Accession No. AFJ60402) belonging to the GH1 family protein. The multiple sequence alignment of the amino acid sequence of BglB with highly homologous GH1 enzymes was performed (Fig. 9). The sequence similarities showed the presence of conserved amino acid residues responsible for its catalytic activity. The catalytic acids $\left(\mathrm{Asn}^{169}-\mathrm{Glu}^{170}\right.$ ), the catalytic nucleophile region $\mathrm{E}^{377} \mathrm{NG}$ and PROSITE motif PS00572 are well conserved in the BglB protein sequence 


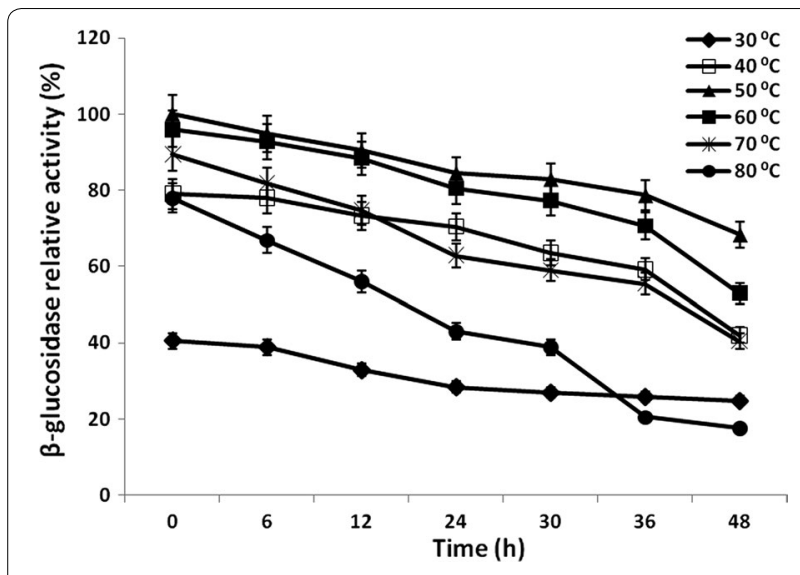

Fig. 8 Temperature stability of $\beta$-glucosidase activity from B. subtilis RA10

which described the characteristic features of GH1 family protein.

For 3D structure prediction, BglB sequence was modelled by SWISS-MODEL (http://swissmodel.expasy. org). Based on the similarity search in the protein database, 2XHY Chain A, crystal structure of $\beta$-glucosidase from $E$. coli was selected as the template for modelling
(Fig. 10). The BglB sequence showed $40 \%$ of identity with the template sequence.

The predicted model was further evaluated for docking studies to compare the binding efficiency of different substrates. Therefore, four different substrates including 4-methylumbelliferyl- $\beta$-D-glucopyranoside, 6-bromo2 -naphthyl- $\beta$-D-glucopyranoside, $\quad 4$-nitrophenyl- $\beta$-Dglucopyranoside and cellobiose were docked against the predicted structural model (Fig. 11). Cellobiose was recorded as the least binding energy with $-7.03 \mathrm{~kJ} /$ mol followed by docking with 4-methylumbelliferyl- $\beta$ D-glucopyranoside with $-6.99 \mathrm{~kJ} / \mathrm{mol}$, least binding energy signifies the strong binding between substrate and enzyme. The inhibition constant for cellobiose substrate was also minimum $(6.97 \mu \mathrm{M})$ as compared with other substrates. The amino acid residue Val37 formed hydrogen bonding with the cellobiose with bond length of $2.237 \AA$, and Trp38, Trp125, Phe41, Ile180, Trp433, Val37, Tyr173, Phe179 were recorded as the interacting residues contributing in the docking.

\section{Discussion}

In the present investigation, the research was focused on the isolation of potent thermotolerant microorganisms capable of producing thermoactive $\beta$-glucosidase from

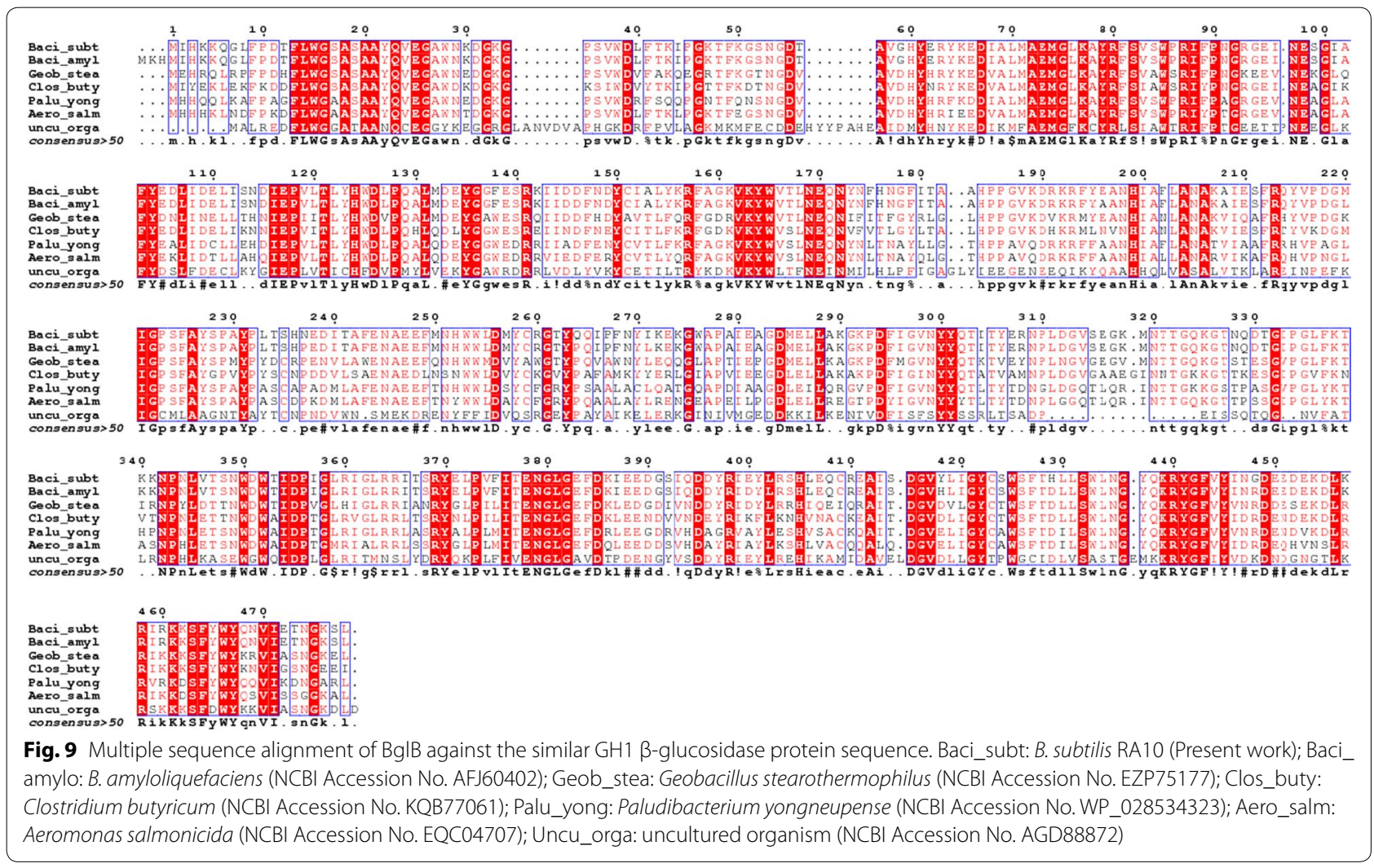




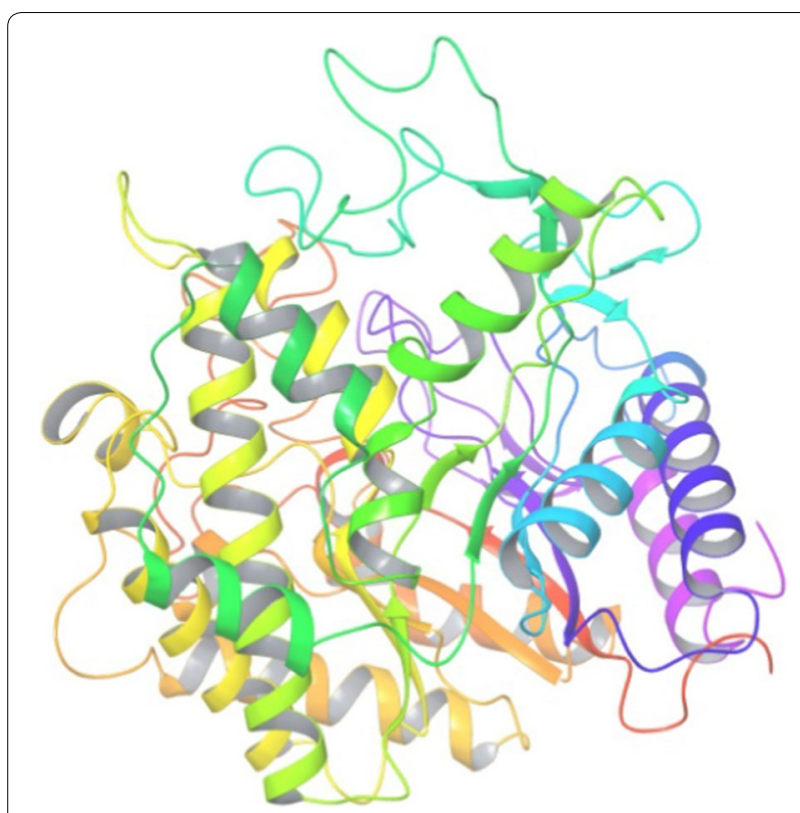

Fig. 10 The predicted structural model of BgIB from B. subtilis RA10 based on structure of $\beta$-glucosidase from E. coli (2XHY_A)

compost and cow dung samples. For this concern, compost and cowdung samples were enriched in the presence of $\alpha$-cellulose and/or cellobiose to isolate promising microbes with potentially high $\beta$-glucosidase production at $45^{\circ} \mathrm{C}$. The total viable count (TVC) of thermotolerant microbes was very low and ranged from $10^{3}$ to $10^{5} \mathrm{CFU}$ (colony forming unit)/g of sample and showed the primary substrate based selection of microbial community. The molecular identification revealed the dominance of two groups including Actinobacteria and Firmicutes. The predominance of these genera in biomass compost and cow dung was previously reported by several researchers [12, 21-23].

The selected microbes were further explored for the quantitative estimation of $\beta$-glucosidase induced by different saccharides at $30-50{ }^{\circ} \mathrm{C}$. All isolates were able to produce $\beta$-glucosidase enzyme at $30-50{ }^{\circ} \mathrm{C}$, but higher enzyme production was observed at $40^{\circ} \mathrm{C}$. Isolate $B$. subtilis RA10 was able to produce maximum $\beta$-glucosidase enzyme among all eleven isolates. Several $\beta$-glucosidases were reported from thermophilic microbes like Caldocellum saccharolyticum [24], Pyrococcus furiosus [25], Microbispora bispora [26], Thermoanaerobacter brockii [27], and were reported to be producer of $\beta$-glucosidase enzyme at high temperature ranging from 40 to $90{ }^{\circ} \mathrm{C}$.

For maximizing the $\beta$-glucosidase production by $B$. subtilis RA10, the optimization of medium components was performed using two statistical design including Taguchi experimental design and Box-Behnken design.
The contribution and ranking of the factors and assigned levels revealed that the carbon source was the most important factor for stimulation on the $\beta$-glucosidase enzyme production by $B$. subtilis RA10. Paddy straw was previously used by researchers to induce the production of hydrolytic enzymes by different microorganisms [20, 28]. The $\mathrm{pH} 8$ was optimum indicating alkaliphilic nature of the $\beta$-glucosidase enzyme.

The concentration of influential medium components was again optimized by Box-Behnken design. This result showed that high loading of carbon source inhibited $\beta$-glucosidase enzyme production by $B$. subtilis RA10. Similar results were obtained with beef extract $-0.29 \%$ (w/v), PEG 6000-0.14\% (v/v) and $\mathrm{NaNO}_{3}-0.12 \%(\mathrm{w} / \mathrm{v})$ where all the optimized values were lower than the highest concentration used in the design. This result showed the significance of optimization experiment where highest enzyme production was achieved by selecting minimal concentration of essential medium components and hence, more applicable for industrial purposes by reducing the cost of enzyme production. Both the statistical designs used in this study including Taguchi experiment and Box-Behnken design were the base for statistical validation of the data. The selection of media components and their concentration can also be analysed by one factor at a time (OFAT) method. However, a large number of experiments and subtle information about the factors interaction effect on enzyme production are the major bottlenecks of OFAT method. The Taguchi and Box-Behnken design help in revealing the statistical significant validation of interaction effect and factor contribution with almost accurate prediction for selected responses. These predictions can be easily conformed by the validation experiment. Therefore, these statistical tools are very commonly used in different bioprocesses.

The cellulase enzyme production is considerably influenced by the incubation temperature and may vary from different microbial strains $[9,20]$. The growth and enzyme production within $30-60{ }^{\circ} \mathrm{C}$ proves the thermotolerant nature of $\beta$-glucosidase production from B. subtilis RA10. The activity was enhanced up to $40{ }^{\circ} \mathrm{C}$ and further decreased at 50 and $60{ }^{\circ} \mathrm{C}$. B. subtilis RA10 belongs to the gram-positive bacteria with high GC content that facilitate the double-stranded structure of their DNA at high temperatures [29]. The existing hypothesis behind the occurrence of thermotolerant enzymes is based on the presence of reverse gyrase [30] or certain dinucleotides [31].

In order to regulate the complete utilization of the medium components as well as to increase $\beta$-glucosidase enzyme production, thermotolerant $B$. subtilis RA10 was cultivated under controlled optimized condition in a bioreactor with $5 \mathrm{~L}$ working volume. After $54 \mathrm{~h}$, 


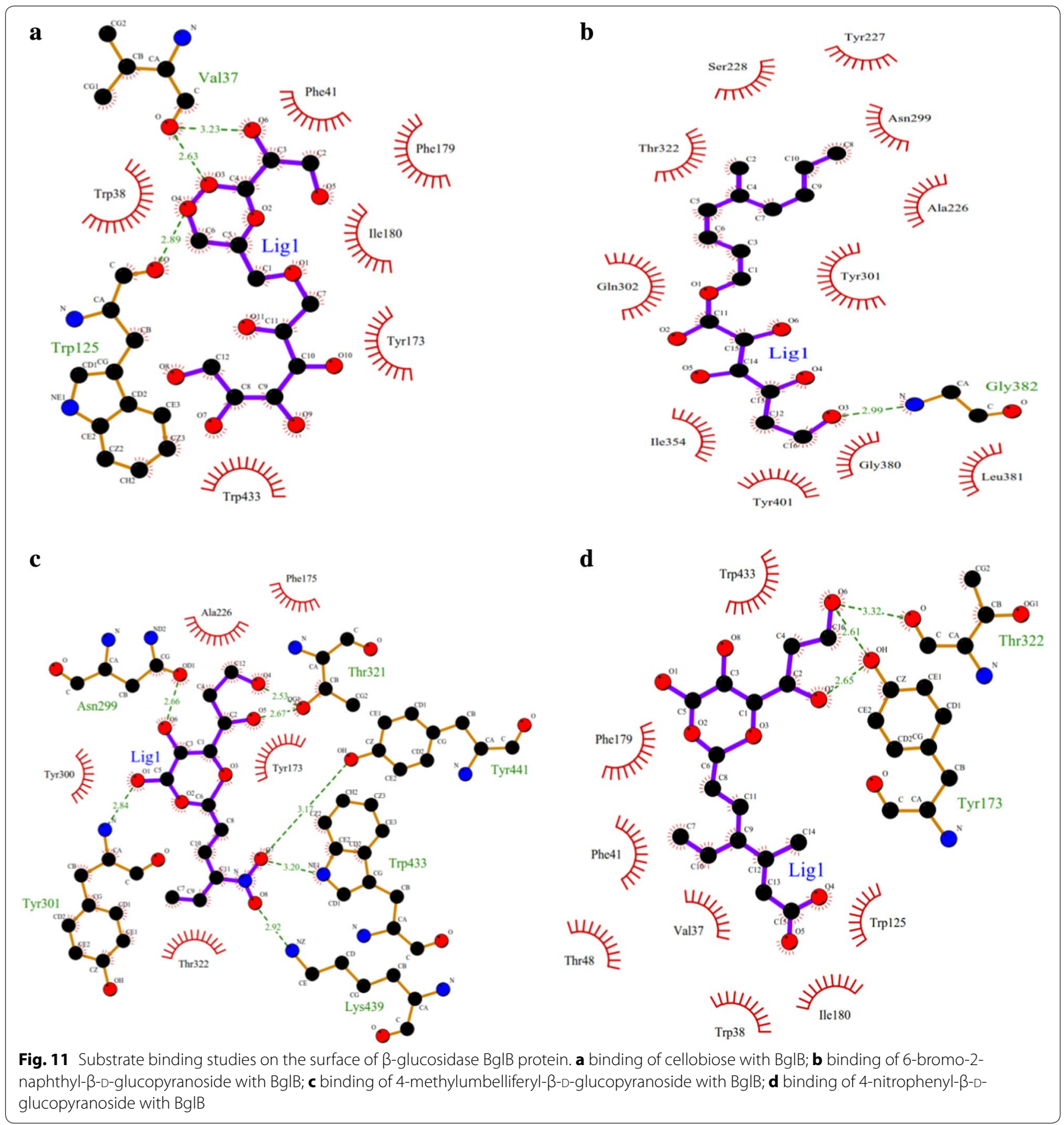

reducing sugar in the medium was consumed completely and simultaneously $\beta$-glucosidase enzyme production was enhanced. The result showed that monomeric sugars in the medium especially glucose inhibited the production of $\beta$-glucosidase [32]. In shake-flask experiment, the maximum $\beta$-glucosidase enzyme production $(58.71 \pm 1.73 \mathrm{IU} / \mathrm{g})$ was achieved after $72 \mathrm{~h}$ of Incubation, whereas in stirred-tank bioreactor, the maximum $\beta$-glucosidase production $(63.29 \pm 1.73 \mathrm{IU} / \mathrm{g})$ was obtained after $80 \mathrm{~h}$ of incubation which was 1.08 -fold higher than the shake flask experiment. This enhancement of $\beta$-glucosidase production was due to controlled distribution of oxygen and $\mathrm{pH}$ into the growth medium throughout the experimentation in stirred tank bioreactor [33]. Subsequently, after achieving the maximum yield, $\beta$-glucosidase production was decreased in both 
the experiments including shake-flask and stirred-tank bioreactor. This might be due to the effect of inhibitors or protease production during the fermentation process [34].

The B. subtilis RA10 was grown under the optimized medium components and the obtained secretome was evaluated for saccharification of alkali-pretreated paddy straw at $50{ }^{\circ} \mathrm{C}$. The experiment was performed to validate the effect of supplementation of $\beta$-glucosidase from B. subtilis RA10 with commercial cellulase (Celluclast ${ }^{\circledR}$ $1.5 \mathrm{~L})$ for more efficient sugar yield. The saccharification result revealed that after supplementation of B. subtilis RA10 secretome, glucose yield was increased by 1.34fold. This result confirmed that $\beta$-glucosidase from $B$. subtilis RA10 acts synergistically with commercial cellulase to serve better release of glucose from pretreated paddy straw. Similarly, many reports are available on the supplementation of $\beta$-glucosidase from external sources into commercial cellulase enzyme to improve the sugar release $[35,36]$. In the present study, the glucose release was much higher as compared with previous reports [10, 37, 38]. Table 9 shows the comparison of different microbial $\beta$-glucosidase enzyme supplementations for improving the biomass hydrolysis.

Furthermore, the full length gene of GH1 family $\beta$-glucosidase was amplified from B. subtilis RA10 and cloned into the pET28a ${ }^{+}$vector for overexpression. Only few GH1 family $\beta$-glucosidase enzymes were overexpressed in the heterologous expression system from different microorganisms like Acidilobus saccharovorans [39], Pyrococcus horikoshii [40], Bacillus sp. [41] and
Streptomyces sp. [42]. The enzyme characterization of purified protein revealed high $\beta$-glucosidase activity even at high temperature and broad range of $\mathrm{pH}$. Most of the $\beta$-glucosidase enzyme from Bacillus origin including B. halodurans [43], B. subtilis [44], Bacillus sp. [41] and Anoxybacillus sp. [45] revealed efficient activity within temperature range of $40-55{ }^{\circ} \mathrm{C}$ at slightly acidic condition. Hence, the results obtained are unique since overexpressed $\beta$-glucosidase enzyme from $B$. subtilis RA10 maintained its activity at high temperature and broad range of $\mathrm{pH}$. The $\beta$-glucosidase enzyme from $B$. subtilis RA10 is thermostable in nature and can be further recycled for the saccharification purpose. According to the Zhang et al. [46], 100-200 g of cellulases is consumed for one gallon of bioethanol production. This high consumption of cellulase enzyme increases the production cost of whole bioethanol process. The involvement of thermostable cellulases may improve the efficiency of the hydrolysis production process. Although cellulases have substrate binding sites which limit the recovery of enzyme after the saccharification, the rate-limiting enzyme of saccharification, $\beta$-glucosidase enzymes do not have any such substrate binding module and hence cannot be adsorbed by the cellulose content [47]. This property of $\beta$-glucosidase enzyme can be utilized to recover this enzyme after saccharification if it retains high activity after the hydrolysis step.

The substrate specificity of overexpressed $\beta$-glucosidase enzyme from $B$. subtilis RA10 was analysed by in silico method. The docking studies revealed that cellobiose was recorded as the least binding energy with $-7.03 \mathrm{~kJ} /$

Table 9 Comparison of different microbial $\beta$-glucosidase enzyme supplementations for improving the biomass hydrolysis

\begin{tabular}{|c|c|c|c|c|c|}
\hline $\begin{array}{l}\beta \text {-Glucosidase producing } \\
\text { microbes }\end{array}$ & Biomass & Enzyme cocktail & $\begin{array}{l}\text { Sugar release } \\
\text { (mg/gds) }\end{array}$ & $\begin{array}{l}\text { Enhanced saccharification } \\
\text { (\%) due to } \beta \text {-glucosidase } \\
\text { supplementation }\end{array}$ & References \\
\hline Humicola grisea var. thermoidea & Sugarcane bagasse & Cellulase of $T$. reesei RP-98 & - & 50 & [36] \\
\hline \multirow{2}{*}{$\begin{array}{l}\text { Microbial } \beta \text {-glucosidases from } \\
\text { cow rumen metagenome }\end{array}$} & \multirow[t]{2}{*}{ Corn stover } & Celluclast, derived from T. reesei & 195.67 & \multirow[t]{2}{*}{20} & \multirow[t]{2}{*}{ [10] } \\
\hline & & $\begin{array}{l}\text { Cellulase supplemented with } \\
\beta \text {-glucosidase }\end{array}$ & 234.8 & & \\
\hline $\begin{array}{l}\beta \text {-Glucosidase gene from cow } \\
\text { rumen }\end{array}$ & Barley straw & $\begin{array}{l}\text { Cellulase from Penicillium } \\
\text { funiculosum }\end{array}$ & - & 150 & [35] \\
\hline Penicillium piceum & Corn stover & $\begin{array}{l}\text { Cellulase from T. reesei; supple- } \\
\text { mented with } \beta \text {-glucosidase }\end{array}$ & - & 15 & [38] \\
\hline \multirow[t]{2}{*}{ Pseudomonas lute aBG8 } & \multirow[t]{2}{*}{ Paddy straw } & Celluclast ${ }^{\circledR} 1.5 \mathrm{~L}$ & 385.28 & \multirow[t]{2}{*}{42.33} & \multirow[t]{2}{*}{ [48] } \\
\hline & & $\begin{array}{l}\text { Celluclast }^{\circledR} 1.5 \mathrm{~L} \text { supplemented } \\
\text { with } \beta \text {-glucosidase from } P \text {. } \\
\text { lutea BG8 }\end{array}$ & 548.4 & & \\
\hline \multirow[t]{2}{*}{ Bacillus subtilis RA10 } & \multirow[t]{2}{*}{ Paddy straw } & Celluclast $^{\circledR} 1.5 \mathrm{~L}$ & 437.79 & \multirow[t]{2}{*}{53.63} & \multirow[t]{2}{*}{ Present work } \\
\hline & & $\begin{array}{l}\text { Celluclast }^{\circledR} 1.5 \mathrm{~L} \text { supplemented } \\
\text { with } \beta \text {-glucosidase from P. } \\
\text { lutea BG8 }\end{array}$ & 582.58 & & \\
\hline
\end{tabular}


mol and signified strong binding between substrate and enzyme. The variation in the binding efficiency of modelled protein with different substrates is important for further studies. This information may infer new insights to develop engineered protein for improvising the enzyme activity at broad range of temperature and $\mathrm{pH}$ so that the enzyme will be more applicable for different industrial purposes.

\section{Conclusions}

In the present study, thermotolerant microbial isolates with $\beta$-glucosidase enzyme characterization and their genetic information gathered from two environmental niches have strengthened the knowledge about $\beta$-glucosidase enzyme. The microbial resource is having potential to produce high titer of $\beta$-glucosidase enzyme with novel and unique characteristics. $\beta$-glucosidase enzymes produced by $B$. subtilis RA10 have shown further improvement in hydrolytic efficiency of biomass which will play a pivotal role in the biorefinery industries. In a nutshell, enzymatic characterization, 3D structure prediction, substrate-based docking studies and hydrolytic potential are sufficient to explain the novelty of thermostable $\beta$-glucosidase from B. subtilis RA10.

\section{Additional file}

Additional file 1: Figure $\mathbf{S 1}$. Qualitative screening of $\beta$-glucosidase producing microbes on agar medium containing esculin with or without glucose. Thermotolerant isolates grown on esculin [A] and esculin with glucose [B]. Figure S2. PCR amplification of $B g / B$ gene and 1437 bp fragment from nuclear DNA of B. subtilis RA10. Lane M, Lambda DNA/EcoRI + HindIII Marker; lane 1, amplified PCR product. Figure S3. Determination of $V_{\max }$ and $K_{\mathrm{m}}$ for purified $\beta$-glucosidase enzyme.

\section{Abbreviations}

RMM: Reese's minimal medium; RSM: response surface methodology; CMC: carboxymethyl cellulose; mM: millimolar; DNA: deoxyribonucleic acid; rRNA: ribosomal ribonucleic acid; PCR: polymerase chain reaction; 3D: three-dimensional; ANOVA: analysis of variance; TVC: total viable count; GH1: glycosyl hydrolase family 1.

\section{Authors' contributions}

RT performed all experiments and analysed the data. SS designed all analytical processes and analysis. PKS performed the bioinformatics analysis. PKSN designed statistical experiments. LN and PS contributed to data analysis, conceptualized, rewrote and edited the manuscript. All authors read and approved the final manuscript.

\footnotetext{
Author details

${ }^{1}$ Enzyme Technology and Protein Bioinformatics Laboratory, Department of Microbiology, Maharshi Dayanand University, Rohtak, Haryana 124001 India. ${ }^{2}$ Division of Microbiology, Indian Agricultural Research Institute, New Delhi 110012 , India. ${ }^{3}$ Indian Institute of Technology Delhi, Hauz Khas, New Delhi 110 016, India. ${ }^{4}$ Design and Mechatronic Division, School of Civil and Mechanical Engineering, Galgotias University, Noida, Uttar Pradesh 201312, India.
}

\section{Acknowledgements}

The authors are thankful to ICAR-Indian Agricultural Research Institute (IARI), New Delhi, India, and Department of Microbiology Maharshi Dayanand University, Rohtak, for providing necessary facilities.

\section{Competing interests}

The authors declare that they have no competing interests.

\section{Availability of data and materials}

This research paper has cited the relevant references as necessary.

\section{Consent for publication}

This research paper does not contain any individual's personal data in any form.

\section{Ethics approval and consent to participate}

This research article does not contain any studies with human participants or animals performed by any of the authors.

\section{Funding}

LN acknowledges National Fund for Basic, Strategic and Frontier Application Research in Agriculture (ICAR-NFBSFARA) for funding the research activities for biofuel project (NFBSFARA/AE-2006/2010-11).

\section{Publisher's Note}

Springer Nature remains neutral with regard to jurisdictional claims in published maps and institutional affiliations.

Received: 20 April 2017 Accepted: 19 October 2017

Published online: 30 October 2017

References

1. Farzad S, Mandegari MA, Guo M, Haigh KF, Shah N, Görgens JF. Multiproduct biorefineries from lignocelluloses: a pathway to revitalisation of the sugar industry? Biotechnol Biofuels. 2017;11:10-87.

2. Mohanram S, Amat D, Choudhary J, Arora A, Nain L. Novel perspectives for evolving enzyme cocktails for lignocellulose hydrolysis in biorefineries. Sustain Chem Process. 2013;1(1):15.

3. Campiche JL, Bryant HL, Richardson JW. Long-run effects of falling celIulosic ethanol production costs on the US agricultural economy. Environ Res Lett. 2010;5(1):014018.

4. Ryu S, Karim MN. A whole cell biocatalyst for cellulosic ethanol production from dilute acid-pretreated corn stover hydrolyzates. Appl Microbiol Biotechnol. 2011;91(3):529-42.

5. Tiwari R, Singh S, Singh N, Adak A, Rana S, Sharma A, Arora A, Nain L. Unwrapping the hydrolytic system of the phytopathogenic fungus Phoma exigua by secretome analysis. Process Biochem. 2014;49(10):1630-6.

6. Keller M, Zengler K. Tapping into microbial diversity. Nat Rev Microbiol. 2004;2(2):141-50.

7. Van Den Burg B. Extremophiles as a source for novel enzymes. Curr Opin Microbiol. 2003;6(3):213-8.

8. Tiwari R, Kumar K, Singh S, Nain L, Shukla P. Molecular detection and environment-specific diversity of glycosyl hydrolase family $1 \beta$-glucosidase in different habitats. Front Microbiol. 2016:7:1597.

9. Tiwari R, Singh S, Shukla P, Nain L. Novel cold temperature active B-glucosidase from Pseudomonas lutea BG8 suitable for simultaneous saccharification and fermentation. RSC Adv. 2014;4(101):58108-15.

10. Del Pozo MV, Fernández-Arrojo L, Gil-Martínez J, Montesinos A, Chernikova TN, Nechitaylo TY, Waliszek A, Tortajada M, Rojas A, Huws SA, Golyshina OV. Microbial $\beta$-glucosidases from cow rumen metagenome enhance the saccharification of lignocellulose in combination with commercial cellulase cocktail. Biotechnol Biofuels. 2012;5(1):73. 
11. Mattéotti C, Thonart P, Francis F, Haubruge E, Destain J, Brasseur C, Bauwens J, De Pauw E, Portetelle D, Vandenbol M. New glucosidase activities identified by functional screening of a genomic DNA library from the gut microbiota of the termite Reticulitermes santonensis. Microbiol Res. 2011;166(8):629-42.

12. Chandna P, Nain L, Singh S, Kuhad RC. Assessment of bacterial diversity during composting of agricultural byproducts. BMC Microbiol. 2013;13(1):99

13. Bhalla A, Bansal N, Kumar S, Bischoff KM, Sani RK. Improved lignocellulose conversion to biofuels with thermophilic bacteria and thermostable enzymes. Bioresour Technol. 2013;128:751-9.

14. Singhania RR, Patel AK, Sukumaran RK, Larroche C, Pandey A. Role and significance of beta-glucosidases in the hydrolysis of cellulose for bioethanol production. Bioresour Technol. 2013;127:500-7.

15. Gupta SK, Shukla P. Advanced technologies for improved expression of recombinant proteins in bacteria: perspectives and applications. Crit Rev Biotechnol. 2016;36(6):1089-98.

16. Ghose TK. Measurement of cellulase activities. Pure Appl Chem. 1987;59(2):257-68.

17. Ghose TK, Bisaria VS. Measurement of hemicellulase activities: part I xylanases. Pure Appl Chem. 1987;59(12):1739-51.

18. Miller GL. Use of dinitrosalicylic acid reagent for determination of reducing sugar. Anal Chem. 1959;31(3):426-8.

19. Montgomery DC. Design and analysis of experiments. New York: Wiley; 2008.

20. Tiwari R, Nain PK, Singh S, Adak A, Saritha M, Rana S, Sharma A, Nain L. Cold active holocellulase cocktail from Aspergillus niger SH3: process optimization for production and biomass hydrolysis. J Taiwan Inst Chem Eng. 2015;56:57-66.

21. Le Goff O, Bru-Adan V, Bacheley H, Godon JJ, Wéry N. The microbial signature of aerosols produced during the thermophilic phase of composting. J Appl Microbiol. 2010;108(1):325-40.

22. Swain MR, Ray RC. Biocontrol and other beneficial activities of Bacillus subtilis isolated from cowdung microflora. Microbiol Res. 2009;164(2):121-30.

23. Wongwilaiwalin $\mathrm{S}$, Laothanachareon T, Mhuantong W, Tangphatsornruang S, Eurwilaichitr L, Igarashi Y, Champreda V. Comparative metagenomic analysis of microcosm structures and lignocellulolytic enzyme systems of symbiotic biomass-degrading consortia. Appl Microbiol Biotechnol. 2013;97(20):8941-54.

24. Love DR, Fisher R, Bergquist PL. Sequence structure and expression of a cloned $\beta$-glucosidase gene from an extreme thermophile. Mol Gen Genet. 1988;213(1):84-92.

25. Kengen SW, Luesink EJ, Stams AJ, Zehnder AJ. Purification and characterization of an extremely thermostable $\beta$-glucosidase from the hyperthermophilic archaeon Pyrococcus furiosus. Eur J Biochem. 1993;213(1):305-12.

26. Wright RM, Yablonsky MD, Shalita ZP, Goyal AK, Eveleigh DE. Cloning, characterization, and nucleotide sequence of a gene encoding Microbispora bispora BglB, a thermostable beta-glucosidase expressed in Escherichia coli. Appl Environ Microbiol. 1992;58(11):3455-65.

27. Prawitwong P, Waeonukul R, Tachaapaikoon C, Pason P, Ratanakhanokchai K, Deng L, Sermsathanaswadi J, Septiningrum K, Mori Y, Kosugi A. Direct glucose production from lignocellulose using Clostridium thermocellum cultures supplemented with a thermostable $\beta$-glucosidase. Biotechnol Biofuels. 2013;6(1):184.

28. Lee YJ, Kim BK, Lee BH, Jo Kl, Lee NK, Chung CH, Lee YC, Lee JW. Purification and characterization of cellulase produced by Bacillus amyoliquefaciens DL-3 utilizing rice hull. Bioresour Technol. 2008;99(2):378-86.

29. Hickey DA, Singer GA. Genomic and proteomic adaptations to growth at high temperature. Genome Biol. 2004;5(10):117.

30. Forterre P. A hot story from comparative genomics: reverse gyrase is the only hyperthermophile-specific protein. Trends Genet. 2002;18(5):236-7.

31. Nakabayashi M, Kataoka M, Mishima Y, Maeno Y, Ishikawa K. Structural analysis of $\beta$-glucosidase mutants derived from a hyperthermophilic tetrameric structure. Acta Crystallogr D Biol Crystallogr. 2014;70(3):877-88.

32. Deshpande V, Eriksson KE, Pettersson B. Production, purification and partial characterization of 1, 4- $\beta$-glucosidase enzymes from Sporotrichum pulverulentum. Eur J Biochem. 1978;90(1):191-8.

33. Beshay $U$, El-Enshasy $H$, Ismail IM, Moawad H, Wojciechowska E, Abd-ElGhany S. $\beta$-Glucanase production from genetically modified recombinant Escherichia coli: effect of growth substrates and development of a culture medium in shake flasks and stirred tank bioreactor. Process Biochem. 2003;39(3):307-13.

34. Balakrishnan $H$, Srinivasan MC, Rele MV. Extracellular protease activities in relation to xylanase secretion in an alkalophilic Bacillus sp. Biotechnol Lett. 1997;19(7):599-601.

35. Gruninger RJ, Gong X, Forster RJ, McAllister TA. Biochemical and kinetic characterization of the multifunctional $\beta$-glucosidase/ $\beta$-xylosidase/aarabinosidase, Bgxa1. Appl Microbiol Biotechnol. 2014;98(7):3003-12.

36. Nascimento CV, Souza FH, Masui DC, Leone FA, Peralta RM, Jorge JA, Furriel RP. Purification and biochemical properties of a glucose-stimulated $\beta$-D-glucosidase produced by Humicola grisea var. thermoidea grown on sugarcane bagasse. J Microbiol. 2010;48(1):53-62.

37. Chen M, Qin Y, Liu Z, Liu K, Wang F, Qu Y. Isolation and characterization of a $\beta$-glucosidase from Penicillium decumbens and improving hydrolysis of corncob residue by using it as cellulase supplementation. Enzyme Microb Technol. 2010;46(6):444-9.

38. Gao L, Gao F, Zhang D, Zhang C, Wu G, Chen S. Purification and characterization of a new $\beta$-glucosidase from Penicillium piceum and its application in enzymatic degradation of delignified corn stover. Bioresour Technol. 2013;147:658-61.

39. Trofimov AA, Polyakov KM, Tikhonov AV, Bezsudnova EY, Dorovatovskii PV, Gumerov VM, Ravin NV, Skryabin KG, Popov VO. Structures of $\beta$-glycosidase from Acidilobus saccharovorans in complexes with tris and glycerol. Dokl Biochem Biophys. 2013;449:99-101.

40. Akiba T, Nishio M, Matsui I, Harata K. X-ray structure of a membranebound $\beta$-glycosidase from the hyperthermophilic archaeon Pyrococcus horikoshii. Proteins Struct Funct Bioinform. 2004;57(2):422-31.

41. Lee JM, Kim YR, Kim JK, Jeong GT, Ha JC, Kong IS. Characterization of salttolerant $\beta$-glucosidase with increased thermostability under high salinity conditions from Bacillus sp. SJ-10 isolated from jeotgal, a traditional Korean fermented seafood. Bioprocess Biosyst Eng. 2015;38(7):1335-46.

42. Mai Z, Yang J, Tian X, Li J, Zhang S. Gene cloning and characterization of a novel salt-tolerant and glucose-enhanced $\beta$-glucosidase from a marine Streptomycete. Appl Biochem Biotechnol. 2013;169(5):1512-22.

43. Naz S, Ikram N, Rajoka MI, Sadaf S, Akhtar MW. Enhanced production and characterization of a beta-glucosidase from Bacillus halodurans expressed in Escherichia coli. Biochemistry. 2010;75(4):513.

44. Kuo LC, Lee KT. Cloning, expression, and characterization of two $\beta$-glucosidases from isoflavone glycoside-hydrolyzing Bacillus subtilis natto. J Agric Food Chem. 2007;56(1):119-25.

45. Chan CS, Sin LL, Chan KG, Shamsir MS, Manan FA, Sani RK, Goh KM. Characterization of a glucose-tolerant $\beta$-glucosidase from Anoxybacillus sp. DT3-1. Biotechnol Biofuels. 2016;9(1):174.

46. Zhang YH, Himmel ME, Mielenz JR. Outlook for cellulase improvement: screening and selection strategies. Biotechnol Adv. 2006;24(5):452-81.

47. Zhu Z, Sathitsuksanoh N, Vinzant T, Schell DJ, McMillan JD, Zhang YH. Comparative study of corn stover pretreated by dilute acid and cellulose solvent-based lignocellulose fractionation: enzymatic hydrolysis, supramolecular structure, and substrate accessibility. Biotechnol Bioeng. 2009;103(4):715-24.

48. Tiwari R, Pranaw K, Singh S, Nain PK, Shukla P, Nain L. Two-step statistical optimization for cold active $\beta$-glucosidase production from Pseudomonas lutea BG8 and its application for improving saccharification of paddy straw. Biotechnol Appl Biochem. 2016;63(5):659-68. 